\title{
Programming CAR T cells to enhance anti-tumor efficacy through remodeling of the immune system
}

\author{
Xiaohui Wang ${ }^{1,2,3}$, Zhiqiang $\mathrm{Wu}^{3}$, Wei Qiu ${ }^{2}$, Ping $\mathrm{Chen}^{1}$, Xiang Xu $(\bowtie)^{2}$, Weidong Han $(\bowtie)^{3}$ \\ ${ }^{1}$ College of Biotechnology, Southwest University, Chongqing 400715, China; ${ }^{2}$ State Key Laboratory of Trauma, Burn and Combined Injury, \\ Department of Stem Cell \& Regenerative Medicine, Daping Hospital and Research Institute of Surgery, Chongqing 400042, China; \\ ${ }^{3}$ Molecular \& Immunological Department, Bio-therapeutic Department, Chinese PLA General Hospital, Beijing 100853, China
}

(C) The Author(s) 2020. This article is published with open access at link.springer.com and journal.hep.com.cn

\begin{abstract}
Chimeric antigen receptor (CAR) $T$ cells have been indicated effective in treating $B$ cell acute lymphoblastic leukemia and non-Hodgkin lymphoma and have shown encouraging results in preclinical and clinical studies. However, CAR T cells have achieved minimal success against solid malignancies because of the additional obstacles of their insufficient migration into tumors and poor amplification and persistence, in addition to antigen-negative relapse and an immunosuppressive microenvironment. Various preclinical studies are exploring strategies to overcome the above challenges. Mobilization of endogenous immune cells is also necessary for CAR T cells to obtain their optimal therapeutic effect given the importance of the innate immune responses in the elimination of malignant tumors. In this review, we focus on the recent advances in the engineering of CAR T cell therapies to restore the immune response in solid malignancies, especially with CAR T cells acting as cellular carriers to deliver immunomodulators to tumors to mobilize the endogenous immune response. We also explored the sensitizing effects of conventional treatment approaches, such as chemotherapy and radiotherapy, on CAR T cell therapy. Finally, we discuss the combination of CAR T cells with biomaterials or oncolytic viruses to enhance the anti-tumor outcomes of CAR $T$ cell therapies in solid tumors.
\end{abstract}

Keywords CAR T cells; immunoregulatory molecules; endogenous immune response; solid malignancies

\section{Introduction}

Along with surgery, chemotherapy, and radiotherapy, immunotherapy is considered an important pillar of cancer treatment. Immunotherapies, such as those using chimeric antigen receptor (CAR) T cells and checkpoint inhibitors, utilize the host's own immune system to exert anti-tumor effects. Immunotherapy was the subject of the 2018 Nobel Prize in Physiology or Medicine for its favorable efficacy in cancer treatment.

CAR T cell therapy is a precise immunotherapy in which genetically engineered $\mathrm{T}$ cells identify tumor cells expressing specific antigens. CARs are recombinant receptors composed of three parts: an extracellular antigen recognition domain, a $\mathrm{T}$ cell receptor (TCR) transmembrane and hinge domain, and an intracellular signal transduction

Received August 10, 2019; accepted December 18, 2019

Correspondence: Weidong Han, hanwdrsw69@yahoo.com; XiangXu, xiangxu@tmmu.edu.cn domain. CAR-expressing T cells can elicit specific immune responses by specifically recognizing a tumor-associated antigen (TAA) and activating $\mathrm{T}$ cells via the signal transduction and hinge domain. In recent years, CAR T cells have shown encouraging results in both preclinical and clinical studies [1-6]. The US Food and Drug Administration (FDA) and European Medicines Agency approved two CAR $\mathrm{T}$ cell treatments for cancer immunotherapy, namely, tisagenlecleucel, and axicabtagene ciloleucel in 2017 and 2018, respectively [7-9]. Although CAR T cells have improved the outcomes of patients with hematologic malignancies, numerous challenges remain in the treatment of solid malignancies, including the difficulty in identifying ideal target tumor antigens, restricted trafficking of CAR $\mathrm{T}$ cells, decreased persistence and expansion of CAR T cells, antigen-negative relapse, and the susceptibility of CAR T cells to the immunosuppressive tumor microenvironment (TME). Preclinical studies are exploring strategies to overcome the above challenges and to increase the efficacy of CAR $\mathrm{T}$ cells in solid malignancies. To overcome the challenge posed by the 
lack of ideal antigens in solid tumors, researchers have altered the CAR designs to include dual and triple CARs [10-13]. T cells are transduced with two or three CARs capable of simultaneously recognizing two or three antigens. Ruella et al. reported that dual CD19 and CD123 CAR T cells demonstrated superior in vivo activity against B cell acute lymphoblastic leukemia (B-ALL) compared with single CAR $\mathrm{T}$ cells [12]. Recently, Bielamowicz et al. showed that trivalent CAR $\mathrm{T}$ cells (cotargeting human epidermal growth factor receptor 2 (HER2), interleukin (IL)-13 receptor $\alpha 2$ (IL13R $\alpha 2$ ), and ephrin type-A receptor 2 (EphA2)) captured nearly $100 \%$ of tumor cells tested in their cohort [13].

The introduction of suicide genes or transient mRNA to CAR T cells can control the lifespan of these cells to reduce treatment-related toxicity [14-18]. Furthermore, local administration of CAR $\mathrm{T}$ cells has been explored to enhance $T$ cell trafficking into tumor tissues [19-22]. Varying methods have been explored to deliver chemokine receptors into CAR T cells because effective trafficking is also interrupted by the mismatch between the chemokine receptors expressed by CAR $\mathrm{T}$ cells and the chemokines expressed by tumors [23].
Additionally, the hostile and immunosuppressive TME impedes the activity of CAR T cells [24-26]. The TME is a complex system that can disturb the anti-tumor function through various immunosuppressive signals [27-29]. Therefore, coordinative innate immune responses inside the TME, including blocking the suppressing immune signals and activating the stimulatory signaling, may elicit effective immune effects (Fig. 1). Blocking suppressive signals, such as programmed cell death-1 (PD-1)/programmed death ligand-1 (PD-L1) signals and immunosuppressive cytokines, potentially heightens CAR T cellmediated tumor immunity. Cytokines are pleiotropic to the endogenous immune system, and their addition enhances the anti-tumor effect of CAR T cells; to date, several cytokines, including IL-12 [30-32], IL-15 [33], IL-18 [34], and tumor necrosis factor (TNF) receptor superfamily member 14 [35], have been adopted to arm CAR T cells. In addition, co-administration strategies with conventional treatment approaches, such as chemotherapy and radiotherapy, and tumor vaccines/oncolytic viruses (OVs) or biomaterials play an important role in enhancing CAR T cell outcomes in solid tumors. In this review, we surveyed strategies for engineering CAR $\mathrm{T}$ cells that not only
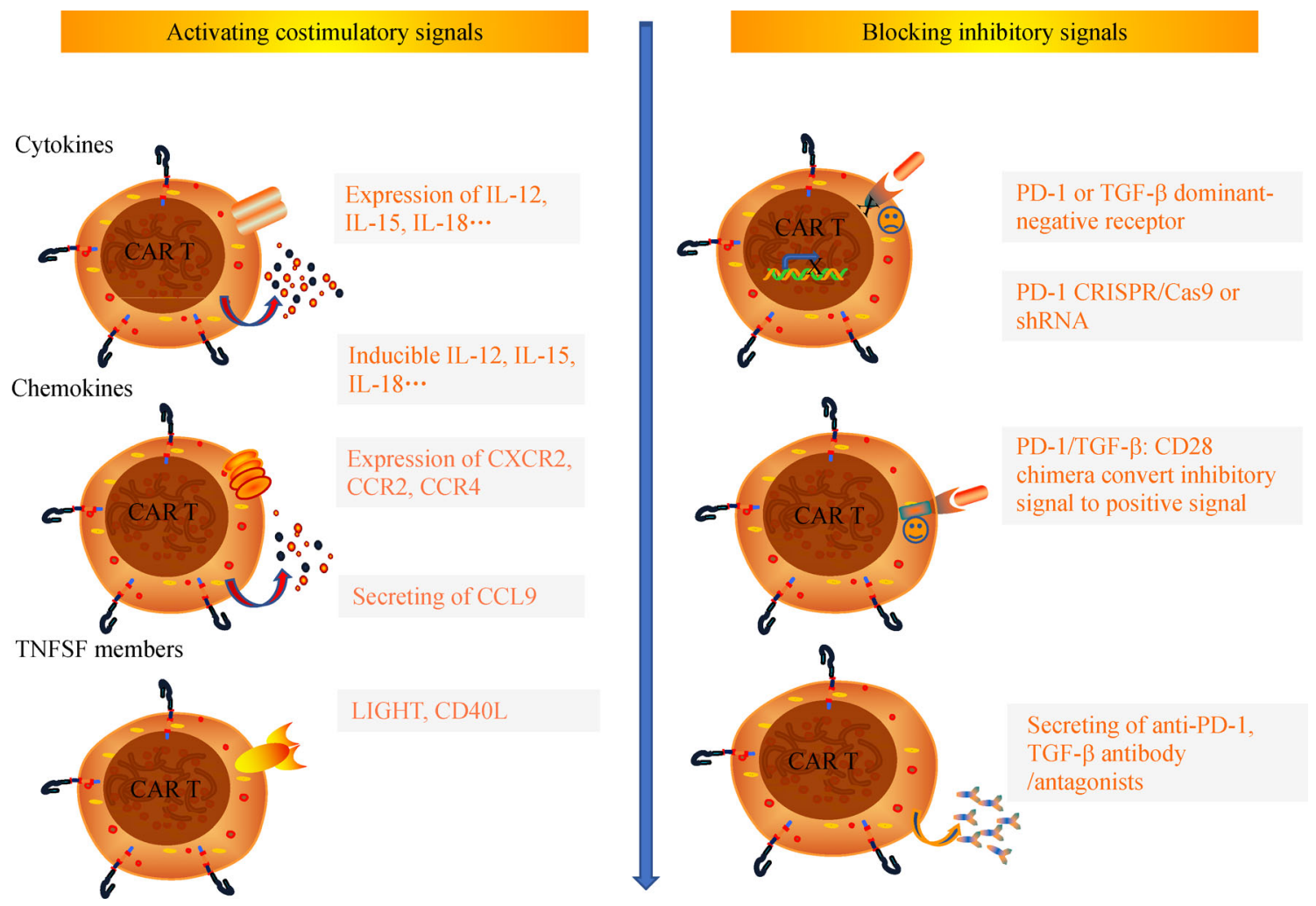

Fig. 1 Strategy for engineering CAR T cells through triggering comprehensive endogenous anti-tumor immune responses. T cell costimulatory (left) and/or inhibitory (right) pathways can be targeted to enhance CAR T cell therapy in solid tumors. CAR T cells are genetically engineered to express/ secrete cytokines and/or chemokines, such as IL-18, IL-15, IL-12, IL-7, chemokine (C-C motif) ligand 19 (CCL19), and tumor necrosis factor superfamily (TNFSF) members. CAR T cells coordinate with inhibitory signals, including immune checkpoints (PD-1/PD-L1) and transforming growth factor $\beta$ (TGF- $\beta$ ), to boost immune responses. 
augment direct anti-tumor effectors but also trigger comprehensive endogenous anti-tumor immune responses (Fig. 2).

\section{Targeting cytokines to boost immune responses}

\section{Combination with IL-12}

IL-12 is a heterodimeric cytokine that is physiologically produced in antigen-presenting cells (APCs), neutrophils, and macrophages [36]. As a potent immune stimulatory cytokine, IL-12 is usually used as a single agent or therapeutic adjuvant to initiate innate immune response [37]. In an early phase trial, IL-12 produced toxicity in several tissues [30,37]. IL-12 was delivered directly to the tumor lesion to overcome this shortcoming; this method was proven safe and elicited clinical responses. This result spurred efforts to deliver IL-12 to engineered CAR T cells. Engineered CAR T cells with an inducible and constitutive IL-12 cassette support the anti-tumor cytotoxicity of CAR $\mathrm{T}$ cells and the reprogrammed immune response.

Wagner et al. engineered Epstein-Barr virus-targeted cytotoxic $\mathrm{T}$ cells to constitutively express IL-12 [38], elevating the Th1 cytokine levels and reducing the production of Th2 cytokines. Additionally, IL-12-transduced $\mathrm{T}$ cells demonstrated a proliferative advantage in the inhibitory environment. This finding was further confirmed by another study that modified CAR19 $\mathrm{T}$ cells to constitutively secrete IL-12 (CAR19/IL-12 T cells) and demonstrated increased cytotoxic capacity and resistance to the suppression of Treg cells [39]. Constitutive secretion of IL-12 by CAR19 T cells has also been verified by the Brentjen's group, who showed that CAR19/IL-12 T cells retained a central memory-effector phenotype and significantly increased the anti-tumor efficacy [32].

However, the IL-12 dose is hard to determine by a constitutive expression strategy, and supratherapeutic levels restrict $\mathrm{T}$ cell expansion and limit their therapeutic efficacy. These issues favor modified CAR $\mathrm{T}$ cells with inducible IL-12 (iIL-12), which is activated and released depending on whether CAR $\mathrm{T}$ cells recognize the target cells $[40,41]$. To date, several preclinical and clinical studies have demonstrated the enhanced anti-tumor activity of iIL-12-secreting CAR T cells.

Chmielewski et al. first confirmed that inducible release of IL-12 incarcinoembryonic antigen-specific CAR T cells enhanced the inflammatory response and destruction of tumor cells with antigen loss [41]. Koneru et al. further demonstrated that IL-12-secreting mucin 16 (MUC-16) CAR T cells enhanced the anti-tumor efficacy, prolonged the persistence of $\mathrm{T}$ cells, and modulated the TME in an ovarian cancer model $[42,43]$; these results were translated into a phase I clinical trial. Recently, a study on hepatocellular carcinoma showed that inducible expression of IL-12 in glypican-3 (GPC3) CAR T cells enhanced their infiltration and persistence, and that these cells demonstrated potent activity against GPC 3-expressing tumors without evident toxicity [44]. Table 1 summarizes the ongoing clinical trials investigating the combination of CAR T cells with IL-12 in cancer immunotherapy.

Thus, a lasting accumulation of IL-12 in the CAR T cell overcomes the limitation of CAR $\mathrm{T}$ cell therapy by remodeling the innate immune response.
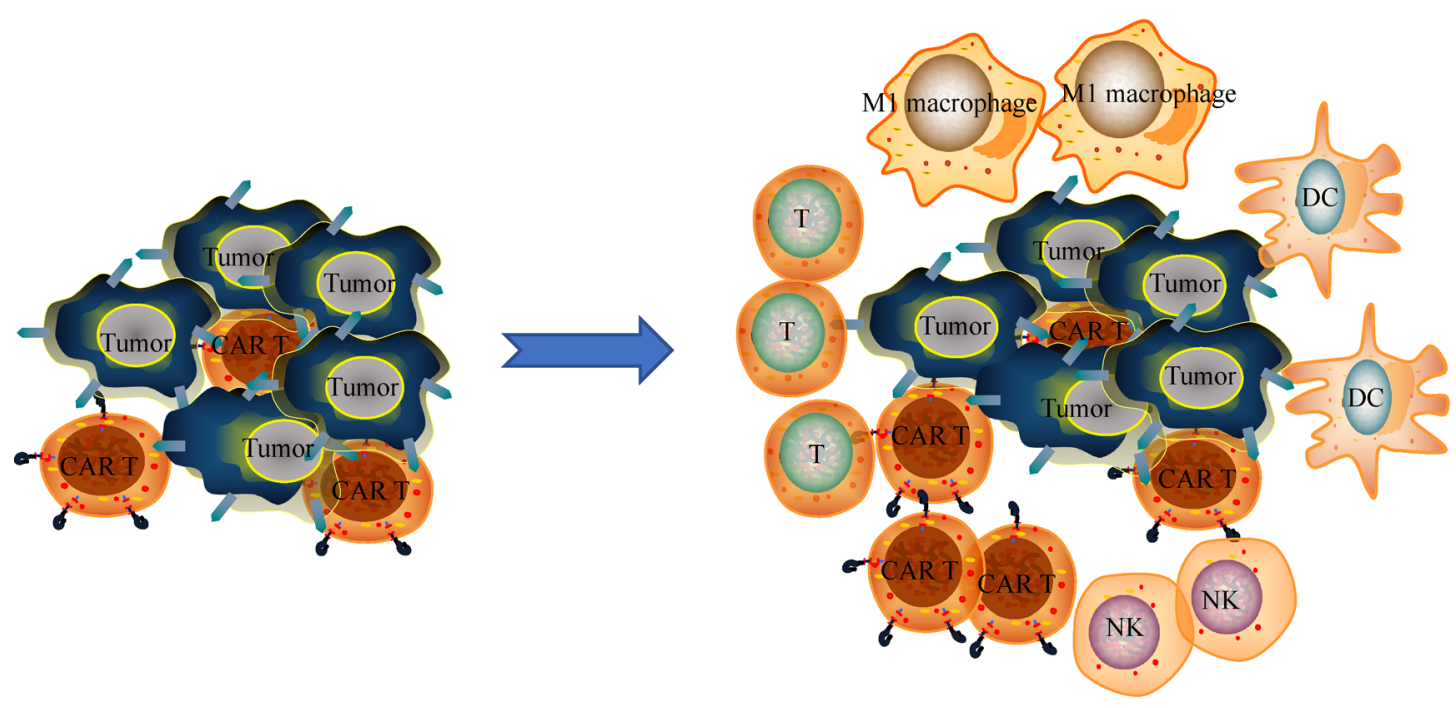

Fig. 2 CAR T cells engineered to co-express/release immune-stimulatory molecules or block immune-inhibitory molecules indirectly mobilize the endogenous immune response by enhancing the activation and recruitment of immune cells, such as M1 macrophages, natural killer (NK) cells, T cells, and dendritic cells (DCs), and by overcoming the inhibitory microenvironment. 


\begin{tabular}{|c|c|c|c|c|c|c|}
\hline Module & Antigen & Phase & Clinical trial ID & Disease condition & Status & Sponsor \\
\hline$\overline{\mathrm{IL}-12}$ & MUC16ecto & I & NCT02498912 & Serous ovarian, PPC, FTC & Recruiting & $\begin{array}{l}\text { Memorial Sloan Kettering } \\
\text { Cancer Center }\end{array}$ \\
\hline IL-12 & EGFR & I & NCT03542799 & Metastatic colorectal cancer & $\begin{array}{l}\text { Not yet } \\
\text { recruiting }\end{array}$ & $\begin{array}{l}\text { Shenzhen Second People's } \\
\text { Hospital }\end{array}$ \\
\hline $\begin{array}{l}\text { IL-7 and CCL19 } \\
\text { or IL-12 }\end{array}$ & Nectin4 & I & NCT03932565 & $\begin{array}{l}\text { NSCLC, breast cancer, ovarian } \\
\text { cancer, bladder cancer, pancreatic } \\
\text { cancer }\end{array}$ & Recruiting & $\begin{array}{l}\text { The Sixth Affiliated } \\
\text { Hospital of Wenzhou } \\
\text { Medical University }\end{array}$ \\
\hline IL-15 & GD2 & I & NCT03721068 & Relapsed/refractory neuroblastoma & Recruiting & $\begin{array}{l}\text { UNC Lineberger } \\
\text { Comprehensive } \\
\text { Cancer Center }\end{array}$ \\
\hline IL-15 & GD2 & I & NCT03294954 & Children with neuroblastoma & Recruiting & $\begin{array}{l}\text { Baylor College of } \\
\text { Medicine }\end{array}$ \\
\hline IL-15 & CD19 & $\mathrm{I} / \mathrm{II}$ & NCT03579927 & $\begin{array}{l}\text { MCL, recurrent/refractory DLBCL, } \\
\text { recurrent/refractory FL, refractory } \\
\text { B cell NHL }\end{array}$ & $\begin{array}{l}\text { Not yet } \\
\text { recruiting }\end{array}$ & $\begin{array}{l}\text { M.D. Anderson Cancer } \\
\text { Center }\end{array}$ \\
\hline IL-15 & CD19 & I & NCT03774654 & $\begin{array}{l}\text { Refractory B cell NHL, refractory } \\
\text { B cell SLL, relapsed adult ALL, } \\
\text { relapsed CLL, relapsed NHL }\end{array}$ & $\begin{array}{l}\text { Not yet } \\
\text { recruiting }\end{array}$ & $\begin{array}{l}\text { Baylor College of } \\
\text { Medicine }\end{array}$ \\
\hline IL-7/IL-15 & CD19 & $\mathrm{I} / \mathrm{II}$ & NCT02652910 & $\begin{array}{l}\text { Recurrent adult DLCL, recurrent FL, } \\
\text { recurrent MCL, stage III/IV adult } \\
\text { DLCL, stage III/IV FL, stage III/IV } \\
\text { MCL }\end{array}$ & Recruiting & $\begin{array}{l}\text { Xinqiao Hospital of } \\
\text { Chongqing }\end{array}$ \\
\hline IL-15 & CD19 & $\mathrm{I} / \mathrm{II}$ & NCT03056339 & $\begin{array}{l}\text { B-lymphoid malignancies, ALL, CLL, } \\
\text { NHL }\end{array}$ & Recruiting & $\begin{array}{l}\text { M.D. Anderson } \\
\text { Cancer Center }\end{array}$ \\
\hline IL-7 and CCL19 & CD19 & II & NCT03929107 & B cell lymphoma & Recruiting & Wenbin Qian \\
\hline CCR4 & CD30 & I & NCT03602157 & $\begin{array}{l}\text { Lymphoma, NHL, immune system } \\
\text { diseases, immunoproliferative } \\
\text { disorders, lymphatic diseases, lympho } \\
\text { proliferative disorders, neoplasms, } \\
\text { cutaneous lymphoma, cutaneous ALCL, } \\
\text { MF, SS, lymphomatoid papulosis }\end{array}$ & Recruiting & $\begin{array}{l}\text { UNC Lineberger } \\
\text { Comprehensive Cancer } \\
\text { Center }\end{array}$ \\
\hline
\end{tabular}

Abbreviations: NCT, clinicaltrials.gov identification number; NHL, non-Hodgkin lymphoma; FL, follicular lymphoma; PPC, primary peritoneal carcinoma; FTC, fallopian tube carcinoma; B cell SLL, B cell small lymphocytic lymphoma; ALCL, anaplastic large cell lymphoma; MF, mycosis fungoides; SS, Sezary syndrome; ALL, acute lymphocytic leukemia; CLL, chronic lymphocytic leukemia; MCL, mantle cell lymphoma; DLCL, diffuse large cell lymphoma; CCR, chemokine receptor; CCL, chemokine ligand.

\section{Combination with IL-15}

The prosurvival cytokine IL-15 is produced by monocytes, macrophages, and DCs. IL-15 reverses T cell anergy, inhibits activation-induced cell death, and enhances the anti-tumor activity of $T$ cells [45-48]. Notably, studies demonstrated that elevated levels of IL-15 in the TME of patients with rectal cancer are associated with increased $\mathrm{T}$ cell infiltration and increased survival. As an immunotherapeutic agent, IL-15 is required for the production of congenital $\mathrm{T}$ cells, which are involved in immune surveillance and impede tumor growth [45,49-51]. Hsu et al. investigated the biological activity of constitutive IL15 expression in $\mathrm{T}$ cells and discovered that IL-15expressing T cells showed enhanced persistence, continued proliferation, and resistance to apoptosis [52].

Recently, research demonstrated that transgenic expression of IL-15 is an appealing strategy to enhance CAR T cell function. A study by Hurton's group revealed that co-expressing CAR19 with a membrane-bound chimeric
IL-15 augmented T cell survival, increased the persistence of a memory stem cell phenotype in T cells, and resulted in superior anti-tumor effects in vivo [45]. Krenciute's group also verified that transduction of IL-15 in IL-13R $\alpha 2$-CAR $\mathrm{T}$ cells in solid tumor resulted in substantial proliferative capacity, and this IL-15-transduced IL13R $\alpha 2$-CAR T cells showed a strong proliferative capacity, high cytokine secretion capacity, and pronounced survival advantages in glioblastoma [53].

However, similar to IL-12, high exposure to IL-15 causes aberrant proliferation of T cells and adverse events, such as autoimmune disease [45]; in addition, chronic stimulation by IL-15 promotes the proliferation and survival of several types of tumor cells [54-56]. Therefore, co-expressing a suicide gene (e.g., inducible caspase 9 (iCaspase9)) with cytokine transgenes has become a reliable method for eliminating IL-15 transgenic cells as required. Hoyos' group incorporated the IL-15 gene and the iCaspase9 suicide gene into CAR19 T cells (iC9/ CAR.19/IL-15); as predicted, these cells enhanced the 
expansion and reduced the expression of the inhibitor signal, and iCaspase9 effectively cleared the T cells [33]. This "safety switch" has increased the potential clinical applicability of IL-15 in CAR T cell immunotherapy. Table 1 summarizes the ongoing clinical trials investigating the combination of CAR T cells with IL-15 in cancer immunotherapy. In summary, IL-15 provides a desired signal for the long-lasting immunosurveillance and preserves the therapeutic potential of CAR T cells.

\section{Combination with IL-18}

IL-18 is an IL-1 family cytokine that regulates the immune system by stimulating the interferon- $\gamma$ secretion. Clinical administration of IL-18 is safe, and several adverse events have been observed in patients treated with IL-18 [57]. Systemic administration of IL-18 can cause inflammatory responses [58], making the release of IL-18 a promising function of engineered CAR T cells.

$\mathrm{Hu}$ and colleagues reported that IL-18-secreting CAR19 $\mathrm{T}$ cells have improved anti-tumor efficacy in hematologic malignancies [59], and this effect has also been verified in solid tumors. Chmielewski's and Abken's groups demonstrated that IL-18 expression in CAR T cells can alter the immunosuppressive microenvironment by activating DCs, recruiting NK cells, inhibiting Treg cells, and increasing tumor-associated M1 macrophages. IL-18 released by CAR $\mathrm{T}$ cells eradicated the pancreatic cancer and metastatic lung cancer in solid tumor models [34]. IL-18 secretion promotes CAR $\mathrm{T}$ cell proliferation and persistence and the anti-tumor activity in vivo. Furthermore, IL18-strengthened CAR T cells can evoke potent endogenous anti-tumor immune responses [60]. However, all published data are from the preclinical models, and we anticipate the translation of these results into clinical trials.

\section{Combination with other cytokines}

In addition to the above cytokines, the IL-7 signal is a potent stimulator of T cell proliferation and expansion [61], and the expression of IL-7R $\alpha$ improves the function and efficacy of CAR T cells in solid tumor environments. As reported, CAR T cells co-expressing an IL-7 cytokine receptor (C7R) had increased $\mathrm{T}$ cell proliferation and survival and enhanced anti-tumor activity in metastatic neuroblastoma and orthotopic glioblastoma xenograft models [62]. Table 1 summarizes the ongoing clinical trials investigating the combination of CAR $\mathrm{T}$ cells with IL-7 in cancer immunotherapy.

IL-21 is another cytokine that is combined with CAR T cells. In melanomas, IL-21-producing CAR $\mathrm{T}$ cells increased $\mathrm{T}$ cell persistence, elevated memory CAR $\mathrm{T}$ cell survival, and were highly efficacious in promoting tumor eradication [63].

\section{Targeting chemokines}

In addition, CAR $\mathrm{T}$ cells have been engineered to constitutively or conditionally secrete cytokines, and numerous methods have been used to engineer CAR T cells with chemokines to restore the endogenous immune system and to potentiate their anti-tumor efficacy $[33,42,59,64,65]$.

Chemokines are secreted proteins that mediate immune cell trafficking to specific tissues, and their expression is positively correlated with tumor-infiltrating lymphocytes (TILs) and with postoperative survival [66]. Chemokines must match their receptors, allowing $\mathrm{T}$ cells to penetrate into tumors. However, chemokine receptors expressed by $\mathrm{T}$ cells often mismatch tumor chemokines, thereby affecting $T$ cell infiltration into the tumor bed [67]. Given the major role of chemokines and their receptors in regulating trafficking and homing of $\mathrm{T}$ lymphocytes, varying methods have been explored to engineer chemokine receptors into CAR T cells to improve CAR T cell migration and infiltration and to enhance the infiltration of other immune cells, such as T cells and DCs, into tumors [68-77].

CAR30 T cells co-expressing CCR4 improve the homing of CAR30 T cells to Hodgkin lymphoma (HL) and thereby enhance the anti-tumor effects [78]. In solid tumors, C-X-C motif chemokine receptor 2-expressing CAR $\alpha v \beta 6 \mathrm{~T}$ cells elicited superior anti-tumor activity in the xenograft models of ovarian and pancreatic tumors [79]. CCR2b-expressing disialoganglioside (GD2) CAR T cells showed improved homing to CCL2-secreting neuroblastomas and showed anti-tumor activity in vivo [71]. Injection of CCR2b-co-expressing meso-CART cells in an immunodeficient mouse model resulted in increased $\mathrm{T}$ cell infiltration and anti-tumor activity [72]. CAR T cells that are simultaneously modified with cytokines and chemokines also exhibit enhanced anti-tumor function. IL-7 enhances the proliferation and survival of $\mathrm{T}$ cells [80-82], and CCL19 is a chemoattractant for T cells and other immune cells $[83,84]$; IL-7 and CCL19-expressing mesoCAR T cells showed improved therapeutic effects against solid tumors, enhanced $\mathrm{T}$ cell activation, increased the development of memory $\mathrm{T}$ cells, and enhanced the infiltration of T cells and DCs into tumor tissues $[67,85]$. Table 1 summarizes the ongoing clinical trials investigating the combination of CAR T cells with chemokines in cancer immunotherapy.

\section{Targeting the TNFSF members}

\section{Combination with LIGHT}

LIGHT is a member of the TNFSF14 and is an immunostimulatory cytokine [86]. Light is mainly 
expressed in immature DCs and activated T cells. LIGHT can bind to two different receptors, namely, herpesvirus entry mediator (HVEM), and lymphotoxin $\beta$ receptor (LT $\beta R$ ), to interact with stromal cells, DCs, NK cells, T cells, and tumor cells [87-89]. LIGHT delivers costimulatory signals to $\mathrm{T}$ cells by binding to HVEM [90] and forms secondary and tertiary lymphoid structures by binding to LT $\beta R$ [ 89,91$]$.

Notably, overexpression of LIGHT in cancer can increase the number of TILs and their activation status, thereby upregulating the anti-tumor immune responses [92]. Targeting tumor tissue with LIGHT increases the recruitment and retention of tumor effector cells, directly or indirectly inducing strong anti-tumor immunity to inhibit primary tumor growth and eradicate metastasis. LIGHT expressed in tumor cells forms a lymphoid-like structure that directly activates $\mathrm{T}$ cells, resulting in tumor regression [93,94]. Fu et al. demonstrated that LIGHT expression in primary tumors or liver metastases stimulates lymphocyte proliferation and activates tumor cell-specific immune responses, leading to tumor regression or slowing down of liver metastasis. Recently, this group generated an anti-epidermal growth factor receptor (EGFR)-hmLIGHT fusion protein against EGFR-expressing tumor tissues. Strikingly, this fusion protein caused complete regression of EGFR-expressing tumors. Together, these results demonstrate that LIGHT overcomes tumor resistance to PD-1 by sufficiently increasing $\mathrm{T}$ cell infiltration and by generating memory cells. These data suggest that a proper combination of LIGHT with immunotherapy may enhance the immunotherapeutic effect [95]. Our team is conducting a study of the combination of LIGHT with CAR T cells to enhance the anti-tumor efficacy of CAR T cells against solid tumors on the basis of the immunostimulatory activity and anti-tumor immune response of LIGHT.

\section{Combination with CD40 ligand (CD40L)}

CD40L is another member of the TNF gene superfamily, and as a costimulatory molecule, it is involved in tumorigenesis and tumor immunosurveillance [96]. CD40L binds to its receptor, CD40, which is expressed mainly in various immune and nonimmune cells, including $\mathrm{B}$ cells, DCs, and macrophages. The CD40L/CD40 pathway is involved in regulating immune function through various mechanisms, such as via modulating B cell activation and DC antigen presentation, affecting T cell proliferation and cytokine secretion, reversing CD8 T cell depletion, and generating the memory phenotype [97102]. In addition, the $\mathrm{CD} 40 \mathrm{~L} / \mathrm{CD} 40$ pathway exhibits direct anti-tumor activity in various carcinoma cells, such as breast carcinoma, squamous cell carcinoma, epithelial carcinoma, and glioma cells, by influencing the balance between apoptotic and survival signals [103-105].

CD40L also enhances the anti-tumor activity by increasing the immunogenicity of malignant cells. This finding was confirmed by William's group, who demonstrated that leukemia cells transduced with an anti-CD40L antibody became highly effective APCs, inducing specific cytotoxic $\mathrm{T}$ cells in vitro and enhancing the immune response in patients with CLL [106]. These observations support the clinical exploitation of CD40L in cancer treatment.

Agonistic CD40 monoclonal antibodies (mAbs) have produced objective anti-tumor responses in single-agent studies and in combination with other modalities, such as chemotherapy, vaccines, or other agents. Single agonistic CD40 mAb therapy will be probably effective for B cell lymphoma. However, for solid tumors, CD40 mAbs will be viable in combination with other modalities [107-109]. The anti-tumor activity of recombinant CD40L has also been tested in phase 1 trials, which showed that the infusion of autologous Ad-murine CD40L-modified CLL cells in patients resulted in a reduced leukemic burden and the activation of leukemia-specific T cells, demonstrating the capacity of recombinant $\mathrm{CD} 40 \mathrm{~L}$ to induce an endogenous anti-tumor response [110]. Furthermore, this group conducted other clinical trials of intravenous injection or intranodal direct injection of Ad-human CD40L-modified CLL cells in patients - these treatments were well tolerated and induced biological and clinical responses [111,112].

Whether CD40L can mobilize endogenous immune cells to enhance the CAR T cell anti-tumor response has been confirmed by showing that engineered CAR T cells with constitutively expressed CD40L orchestrate a sustained endogenous anti-tumor response by recruiting tumor-recognizing $\mathrm{T}$ cells. Brentjens et al. showed that the constitutive expression of CD40L by CAR 19 T cells enhanced the cytotoxicity to a panel of CD19-positive tumor cell lines in vitro and extended the survival of xenotransplanted mice with CD19-positive systemic lymphoma [113]. DCs can prime anti-tumor $\mathrm{T}$ cell responses by presenting antigenic peptides to surface TCRs via the major histocompatibility complex (MHC)-I and MHC-II molecules. Kuhn et al. reported that CD40L ${ }^{+}$ CAR T cells activate DCs in vivo, leading to secretion of the proinflammatory cytokine IL-12 by DCs and augmenting the recruitment and cytotoxic function of endogenous tumor-specific cytotoxic $\mathrm{T}$ cells and transferred CAR T cells [114]. Therefore, the combination of CAR T cells with the immunostimulatory molecule CD40L is a promising strategy to ensure the recruitment and cytotoxic function of endogenous immune cells in cancer treatment.

\section{Overcoming immune inhibition to boost immune responses in CAR T cells}

Releasing the brakes of the immune inhibitory system is also an important strategy to boost the immune response 
against tumors. Checkpoint and immunosuppressive cytokines are the main actors that block the immune system from acting on tumors [115].

\section{Targeting immune checkpoints}

T cells express co-inhibitory receptors, such as PD-1 [115], that decrease $\mathrm{T}$ cell-mediated tumor immunity and enhance tumor escape. Blocking antibodies against PD-1/PD-L1 have achieved beneficial activity in clinical practice [116119]. PD-1 disrupts the function of tumor-infiltrating CAR $T$ cells [120-123], indicating that inhibiting PD-1/PD-L1 can increase the anti-tumor activity of CAR T cells.

In hematologic malignancies, PD-1 blockade has been shown to potentially synergize with CAR $T$ cells in preclinical and clinical research. Li et al. engineered CAR19 T cells to constitutively secrete anti-PD-1 scFvs (CAR19.aPD1 $T$ cells), which significantly enhanced $\mathrm{T}$ cell proliferation. In a xenograft mouse model, these CAR19.aPD1 T cells showed significantly enhanced antitumor activity and prolonged overall survival. In addition, decreased level of CAR19.aPD1 T cell exhaustion was observed at the local tumor site [124]. Encouraging data have also emerged from clinical studies; for example, antiPD1 antibodies augment the response of pediatric B-ALL patients to CAR19 T cells [125]. In another small, singlecenter study at the Children's Hospital of Pennsylvania, PD-1 blockade improved the persistence of CAR19 T cells in 14 children with B-ALL who failed in CAR19-T cell therapy, and B cell aplasia was reestablished in three out of six patients treated with a PD-1 inhibitor combined with CAR19-T cells, indicating CAR19-T cell function. Five patients achieved a partial response, and two achieved a complete response [124,126,127]. These studies suggest a potential strategy of combining CAR T therapy with PD-1 blockade in solid cancers.

\section{Combination with anti-PD-1 antibodies}

John et al. first showed that anti-PD-1 antibodies can significantly enhance the therapeutic efficacy of CAR T cells in a mouse solid tumor model. They also discovered that anti-PD-1 antibodies increased Her2 CAR T cell activation and proliferation in vitro, significantly inhibiting the growth in two different Her2 positive tumors. Strikingly, the percentage of myeloid-derived suppressor cells (MDSCs) significantly decreased in mice treated with the combination therapy [128]. A small phase 1 trial on relapsed or refractory neuroblastoma patients by Heczey [49] reported that CAR T cells administered with an antiPD-1 antibody (pembrolizumab) were safe.

However, unlike the above experience in preclinical experiments, pembrolizumab causes no effect on CAR T cell expansion and persistence in patients with neuroblastoma [129], possibly because of the doses and schedules of
PD-1 antibodies affecting their synergy with CAR T cells; this hypothesis has been further verified, that is, high-dose PD-1 antibodies enhanced anti-tumor activity of CAR T cells in a syngeneic breast cancer model [128]; by contrast, low-dose antibodies showed no effect [124]. These results suggest that optimal doses and schedules of PD-1 blockade will be a promising strategy to maximize the synergy of PD-1 blockade and CAR T cells. In addition, Suarez et al. engineered carbonic anhydrase IX-targeted CAR T cells to locally deliver PD-L1 antibodies [130], leading to NK cell recruitments and a fivefold reduction in tumor growth. This result was further verified in a human lung carcinoma xenograft mouse model by Li et al., who also engineered CAR T cells to secrete anti-PD-1 antibodies [124]. They demonstrated that the secreted anti-PD-1 antibodies efficiently reversed the inhibitory effect, diminished $\mathrm{T}$ cell exhaustion, and improved CAR $\mathrm{T}$ cell anti-tumor activity.

\section{Engineering of $P D-1 / P D-L 1$}

Genetic strategies, such as knockdown or knockout of PD1 by suicide gene "safety switch" systems or shRNAs and the incorporation of a PD-1 dominant-negative receptor (DNR), have been used in modified CAR T cells to induce PD-1/PD-L1 blocking.

The PD1:CD28 chimera that converts PD-1 inhibitory signals to the CD28 costimulatory receptor has been used to modify CAR $\mathrm{T}$ cells, and this chimera resulted in enhanced cytotoxic T-lymphocyte (CTL) functionality by increasing cytokine secretion and proliferation and enhancing the expression of effector molecules without leading to CTL exhaustion when engaged with PD-L1-positive tumors [131]. Another genetic strategy to counteract PD-1 inhibitory signaling in CAR $\mathrm{T}$ cells is to knockout or knockdown PD-1. Cherkassky's group generated a PD-1 DNR and shRNA targeting PD-1 in mesothelin-specific CAR T cells, and they observed that this genetic blockade of PD-1 restored the functions of exhausted CAR T cells [24].

The clustered regularly interspaced short palindromic repeats (CRISPR)/CRISPR-associated protein 9 (Cas9) system emerged as an efficient way to strengthen CAR T cell anti-tumor activities. Ren et al. utilized this CRISPR/ Cas9 system to generate PD-1-deficient CAR prostate stem cell antigen (PSCA) T cells [132]. They observed that CD137 was upregulated, and CAR T cell anti-tumor activity was enhanced. A similar result was achieved by Rupp et al., who developed PD-1-deficient CAR19 T cells [133] and observed the augmented CAR T cell killing of tumor cells. This CRISPR/Cas9 approach has also been utilized to disrupt the PD-1 gene locus in mesothelintargeted CAR T cells to enhance tumor control and relapse prevention [134]. 
In conclusion, this part demonstrates the therapeutic promise of integrated immune checkpoint blockade in CAR T cells in boosting immune responses and enhancing the anti-tumor activity of CAR T cells. Table 2 summarizes the ongoing clinical trials investigating the combination of CAR T cells with immune checkpoint blockade in cancer immunotherapy.

\section{Inhibition of immunosuppressive cytokines}

Many cancers produce an immunosuppressive environment by secreting or aberrantly expressing cytokines and their ligands, including TGF- $\beta$, IL- 4 , and colony-stimulating factor-1 (CSF-1), which protect malignant cells from immune destruction and promote tumor formation and

Table 2 Summary of ongoing clinical trials investigating the combination of CAR T cells with immune checkpoint blockade in cancer immunotherapy

\begin{tabular}{|c|c|c|c|c|c|c|}
\hline Module & Antigen & Phase & Clinical trial ID & Disease condition & Status & Sponsor \\
\hline $\begin{array}{l}\text { Expressing PD-1 } \\
\text { antibody }\end{array}$ & $\begin{array}{l}\text { EGFR } \\
\text { family }\end{array}$ & $\mathrm{I} / \mathrm{II}$ & NCT02873390 & $\begin{array}{l}\text { Advanced } \\
\text { malignancies }\end{array}$ & Unknown & Ningbo Cancer Hospital \\
\hline $\begin{array}{l}\text { Expressing PD-1 } \\
\text { antibody }\end{array}$ & $\begin{array}{l}\text { EGFR } \\
\text { family }\end{array}$ & $\mathrm{I} / \mathrm{II}$ & NCT02862028 & $\begin{array}{l}\text { Advanced solid } \\
\text { tumor (lung, liver, } \\
\text { and stomach) }\end{array}$ & Unknown & $\begin{array}{l}\text { Shanghai International } \\
\text { Medical Center }\end{array}$ \\
\hline $\begin{array}{l}\text { Cytoplasmic } \\
\text { activated PD-1 }\end{array}$ & CD19 & I & NCT03540303 & $\begin{array}{l}\text { Refractory/relapsed } \\
\text { B cell lymphoma }\end{array}$ & Recruiting & Henan Cancer Hospital \\
\hline PD-1 knockout & MUC1 & $\mathrm{I} / \mathrm{II}$ & NCT03525782 & $\begin{array}{l}\text { Lung cancer, } \\
\text { NSCLC }\end{array}$ & Recruiting & $\begin{array}{l}\text { The First Affiliated } \\
\text { Hospital of Guangdong } \\
\text { Pharmaceutical } \\
\text { University }\end{array}$ \\
\hline $\begin{array}{l}\text { Expressing PD-1 } \\
\text { antibody }\end{array}$ & Mesothelin & $\mathrm{I} / \mathrm{II}$ & NCT03030001 & $\begin{array}{l}\text { Solid tumor, adult } \\
\text { advanced cancer }\end{array}$ & Unknown & Ningbo Cancer Hospital \\
\hline PD-1 knockout & MUC1 & $\mathrm{I} / \mathrm{II}$ & NCT03706326 & Esophageal cancer & Recruiting & $\begin{array}{l}\text { The First Affiliated } \\
\text { Hospital of Guangdong } \\
\text { Pharmaceutical } \\
\text { University }\end{array}$ \\
\hline $\begin{array}{l}\text { PD-1 and TCR } \\
\text { knocked out }\end{array}$ & Mesothelin & I & NCT03545815 & Solid tumor & Recruiting & $\begin{array}{l}\text { Chinese PLA General } \\
\text { Hospital }\end{array}$ \\
\hline PD-1 knockout & CD19 & I & NCT03298828 & $\begin{array}{l}\text { ALL, Burkitt } \\
\text { lymphoma }\end{array}$ & $\begin{array}{l}\text { Not yet } \\
\text { recruiting }\end{array}$ & $\begin{array}{l}\text { Third Military Medical } \\
\text { University }\end{array}$ \\
\hline $\begin{array}{l}\text { Expressing CTLA-4 } \\
\text { and PD-1 antibodies }\end{array}$ & EGFR & $\mathrm{I} / \mathrm{II}$ & NCT03182816 & $\begin{array}{l}\text { Advanced solid } \\
\text { tumor }\end{array}$ & Unknown & $\begin{array}{l}\text { Shanghai Cell Therapy } \\
\text { Research Institute }\end{array}$ \\
\hline $\begin{array}{l}\text { Expressing CTLA-4 } \\
\text { and PD-1 antibodies }\end{array}$ & MUC1 & $\mathrm{I} / \mathrm{II}$ & NCT03179007 & $\begin{array}{l}\text { Advanced solid } \\
\text { tumor }\end{array}$ & Unknown & $\begin{array}{l}\text { Shanghai Cell Therapy } \\
\text { Research Institute }\end{array}$ \\
\hline $\begin{array}{l}\text { Expressing CTLA-4 } \\
\text { and PD-1 antibodies }\end{array}$ & Mesothelin & $\mathrm{I} / \mathrm{II}$ & NCT03182803 & $\begin{array}{l}\text { Advanced solid } \\
\text { tumor }\end{array}$ & Unknown & $\begin{array}{l}\text { Shanghai Cell Therapy } \\
\text { Research Institute }\end{array}$ \\
\hline PD-1 knockout & Mesothelin & I & NCT03747965 & Solid tumor & Recruiting & $\begin{array}{l}\text { Chinese PLA General } \\
\text { Hospital }\end{array}$ \\
\hline $\begin{array}{l}\text { Transduced with a } \\
\text { PD-1/CD28 chimera } 1 \\
\text { entiviral vector }\end{array}$ & CD19 & I & NCT03932955 & Lymphoma & Recruiting & Peking University \\
\hline $\begin{array}{l}\text { Combination with } \\
\text { anti-PD-1 antibody } \\
\text { (Pembrolizumab) }\end{array}$ & $\begin{array}{l}\mathrm{CD} 19 \\
\text { and CD22 }\end{array}$ & $\mathrm{I} / \mathrm{II}$ & NCT03287817 & $\begin{array}{l}\text { DLBCL, relapsed } \\
\text { or refractory } \\
\text { DLBCL }\end{array}$ & Recruiting & Autolus Limited \\
\hline $\begin{array}{l}\text { Expressing PD-1 } \\
\text { antibody }\end{array}$ & Mesothelin & $\mathrm{I} / \mathrm{II}$ & NCT03615313 & $\begin{array}{l}\text { Advanced solid } \\
\text { tumor }\end{array}$ & Recruiting & $\begin{array}{l}\text { Shanghai Cell Therapy } \\
\text { Research Institute }\end{array}$ \\
\hline $\begin{array}{l}\text { Combination with } \\
\text { anti-PD-1 antibody } \\
\text { (Pembrolizumab) }\end{array}$ & EGFRvIII & I & NCT03726515 & Glioblastoma & Recruiting & $\begin{array}{l}\text { University of } \\
\text { Pennsylvania }\end{array}$ \\
\hline $\begin{array}{l}\text { Incorporation of a } \\
\text { PD-1shRNA } \\
\text { expressing cassette }\end{array}$ & CD19 & I & NCT03208556 & $\begin{array}{l}\text { Relapsed or refractory } \\
\text { B cell lymphoma }\end{array}$ & Recruiting & Peking University \\
\hline
\end{tabular}

Abbreviations: NSCLC, non-small-cell lung carcinoma; ALL, acute lymphoblastic leukemia; DLBCL, diffuse large B cell lymphoma; CTLA-4, cytotoxic Tlymphocyte-associated antigen 4; PD-1, programmed cell death protein 1. 
progression [135-137]. Thus, to provide a clinical benefit to patients with solid tumors, additional engineering is required to protect $\mathrm{CAR} T$ cells from the inhibitory effects of immunosuppressive cytokines.

\section{$T G F-\beta$}

TGF- $\beta$ exhibits antagonistic effects on various immune cells [138-140]. For example, TGF- $\beta$ inhibits CD4 and CD8 $T$ cell activation or cytolytic activity, regulates the polarization of macrophages and inhibits their chemotactic function, inhibits the maturation of DC and NK cells, and induces the apoptosis of B cells [141-143]. Inhibition of the negative effects of TGF- $\beta$ signaling in the cancer microenvironment effectively promotes the anti-tumor effects. Recently, TGF- $\beta$ signal inhibition has gained great interest in combination with CAR T cells for tumor treatment.

Morgan's group in 2013 reported TGF- $\beta$ signal inhibition in CAR T cells; they genetically modified CAR T cells to secrete soluble TGF- $\beta$ receptors or TGF- $\beta$ DNR II (DNRII); TGF- $\beta$ DNR-modified CAR T cells dramatically improved $\mathrm{T}$ cell anti-tumor activity in a melanoma tumor model [144]. However, soluble TGF- $\beta$ receptors expressed by CAR T cells were weak at blocking the TGF- $\beta$ activity, and the reason may be the low concentration of expressed receptor or incapability of the soluble receptors to bind with the TGF- $\beta$ presented on the T cells [145]. Recently, CAR prostate-specific membrane antigen (PSMA) $\mathrm{T}$ cells engineered to co-express TGF- $\beta$ DNR demonstrated enhanced innate and acquired immunity, showing increased proliferation and infiltration, sustained survival and resistance to exhaustion, and enhanced secretion of proinflammatory cytokines. In aggressive human prostate cancer mouse models, TGF- $\beta$-inhibited CAR T cells exhibited augmented anti-tumor activity [146]. The above studies suggest that TGF- $\beta$ DNR expression is an effective way to improve the therapeutic effect of CAR T cells.

Similar to the previously reported PD1:CD28 chimera, Chang et al. also generated a CAR composed of a TGF- $\beta$ binding domain and $\mathrm{CD} 28-\zeta$ stimulatory signaling, thereby effectively converting TGF- $\beta$ from an inhibitor to a stimulator of $\mathrm{T}$ cell growth. TGF- $\beta / \mathrm{CD} 28 \mathrm{CAR} \mathrm{T}$ cells not only retained the cytotoxicity of the $T$ cell itself but also enhanced the anti-tumor efficacy of adjacent $T$ cells and caused no effect on their anti-tumor function by mixing with Treg cells [147]. Based on these results, we believe that CAR $T$ cells expressing TGF- $\beta / C D 28$ have a promising future in the treatment of solid tumors.

In addition, TGF- $\beta$ is used to overcome the immunosuppressive environment, and its capability to enhance the tumor-selective effects of CAR T cells has been explored. Recently, Juan and colleagues designed tumor-specific molecular pattern-activated and regulated $\mathrm{T}$ cells, named SmarT-cells, which are $\mathrm{T}$ cells engineered with three individual receptors that recognize PSCA, TGF- $\beta$, and IL4 and contain intracellular domains important for $\mathrm{T}$ cell activation, co-stimulation, and cytokine support. These SmarT-cells selectively and safely enhance the anti-tumor effects [148]. Overall, these data indicate that the mechanisms targeting TGF- $\beta$ signaling can be combined in various ways with CAR T cells to boost their anti-tumor activity.

\section{$I L-4$}

As a cancer immunotherapeutic agent, IL-4 is highly expressed in a variety of tumors, where it has been reported to promote tumor cell growth and protect tumor cells from apoptosis $[136,149,150]$. Under physiologic conditions, IL4 inhibits the tumor-directed Th1 polarization response and induces the Th2 immune response [151,152]. IL-4 exposure also reduces the cytotoxicity of NK cells in in vitro and in vivo models $[153,154]$. Based on this evidence, IL-4 provides a selective growth signal for regulating CAR T cell expansion and tumor cytolytic activity.

Wilkie and colleagues created $4 \alpha \beta$ (with the ectodomain of IL-4R fused to the endodomain of the shared IL-2/15 $\beta \mathrm{c}$ subunit)-expressing MUC1-targeted CAR $\mathrm{T}$ cells and showed that IL-4 drove the antigen-targeted expansion and potent anti-tumor activity of these CAR T cells. Furthermore, $4 \alpha \beta$ has been co-expressed with a CAR recognizing two additional tumor-associated targets (PSMA and ErbB), and similar results were observed [155]. This finding was further verified by Mohammed and colleagues [156], who co-expressed a IL-4/IL-7-inverted cytokine receptor $(4 / 7$ ICR) generated by fusing the exodomain of the IL-4 receptor with the endodomain of the IL-7 receptor on CAR-PSCA cells; these 4/7 ICR coexpressing CAR-PSCA T cells exhibited enhanced antitumor effects in pancreatic cancer (as characterized by elevated IL-4 levels and PSCA overexpression) $[157,158]$. Collectively, these findings provide proof of principle for the development of IL-4-enhanced CAR T cells for cancer immunotherapy.

\section{$C S F-1$}

CSF-1, also known as macrophage CSF, is a cancerassociated cytokine that is overexpressed in many cancers, such as ovarian cancer, breast cancer, and classical HL, and is correlated with high grade and poor prognosis $[159,160]$. CSF-1 regulates the proliferation and differentiation of monocytic lineage cells [161] through its cell surface receptor (CSF-1R). However, CSF-1 shows no direct effects upon $\mathrm{T}$ cells lacking CSF-1R expression. Therefore, engineering $T$ cells to respond positively to 
CSF-1 might provide a useful means to amplify the antitumor immune response. To examine the CSF-1 responsiveness, Maher and colleagues [162] expressed CSF-1R in human T cells. Soluble CSF-1 synergistically enhanced $\mathrm{T}$ cell proliferation and activation in response to IL-2. In further examinations of whether activation of CSF-1R could enhance the function of CAR T cells, PSMA-specific CAR T cells co-expressing CSF-1R significantly augmented the PMSA-dependent expansion of $\mathrm{T}$ cells and preserved tumor cytolytic activity. These data support the potential of CAR T cells to be genetically modified to acquire responsiveness to CSF-1 and provide proof of principle for a novel strategy to enhance the effectiveness of CAR T cell immunotherapy.

Overall, the data presented here establish that CAR T cells can combine with checkpoint and tumor-derived cytokines to obtain potent co-stimulation of the immune response and enhance their anti-tumor activity in solid tumors.

\section{Combination with oncolytic virotherapy}

OVs mediate their anti-tumor effects through a dual mechanism: selectively lysing cancer cells [163] and providing viral risk signals to enhance effector cell expansion and function $[164,165]$. Several multi-oncolytic virotherapies have received the FDA approval [166]. Currently, renewed attention is focused on selectively expressing OVs in the TME to boost the anti-tumor immune response [167-171]. The combination of OVs with immune checkpoint inhibitors has produced high response rates in patients with advanced melanoma [172175].

OVs also possess the potential to synergize with CAR T cells to mitigate the challenges in the treatment of solid tumors. First, OVs facilitate the trafficking, proliferation, and persistence of CAR T cells in the TME. Second, OVs promote the release of TAAs to induce an adaptive immune response. Moreover, OVs directly enhance the anti-tumor functions of CAR T cells harboring therapeutic transgenes, including those encoding cytokines [176,177], chemokines
[178], and immune checkpoint inhibitors [179-181]. Here, we discuss recent strategies to explore the synergy between CAR T cells and OVs in cancer treatment.

OVs were modified to deliver intratumoral cytokines or chemokines to enhance CAR T cell therapy. June's group [182] reported that oncolytic adenovirus expressing TNF- $\alpha$ and IL-2 robustly increased meso-CAR T cell and host T cell infiltration into the tumor, overcame the immunosuppressive TME, and increased the DC maturation; these results indicate that combining with cytokine-expressing OVs can enhance the efficacy of CAR T cell therapy in solid tumors. Studies have also examined the ability of chemokine-expressing OVs in CAR T cells; a modified oncolytic vaccinia virus expressing CXCL11 successfully recruited $\mathrm{T}$ cells and significantly enhanced the anti-tumor efficacy of meso-CAR $T$ cells [183]. This finding was further demonstrated by Dotti et al., who combined CAR GD2-T cells with OVs expressing the chemokine RANTES and cytokine IL-15, facilitating the migration and survival of CAR $T$ cells and increasing their overall anti-tumor activity in tumor-bearing mice. Checkpoint inhibitors are a natural choice for combination with OVs in cancer therapy [184]. An oncolytic adenovirus expressing a PD-L1 minibody enhanced the anti-tumor effect of HER2 CAR T cells against human solid cancer cells [185]. A similar study created an oncolytic adenovirus construct encoding anti-PD-L1 antibodies and IL-12 and showed augmented therapeutic efficacy of CAR HER2 T cells in primary and metastasized head and neck squamous cell tumors [186].

Moreover, CAR T cells can augment OV anti-tumor function. CAR T cells have been used as a carrier to deliver OVs to the tumor site to protect the viruses from neutralizing antibodies. Various studies have been performed to determine whether CAR T cells could be loaded with OVs and effectively create a dual-pronged anti-tumor agent [187,188]. Bramson et al. [189] demonstrated that murine and human CAR T cells can deposit viruses into the TME and effectively enhance the anti-tumor responses of both approaches. Table 3 summarizes the ongoing clinical trials investigating the combination of CAR T cells with OVs in cancer immunotherapy.

Table 3 Summary of ongoing clinical trials investigating the combination of CART cells with OVs in cancer immunotherapy

\begin{tabular}{|c|c|c|c|c|c|c|}
\hline Module & Antigen & Phase & Clinical trial ID & Disease condition & Status & Sponsor \\
\hline $\begin{array}{l}\text { Oncolytic } \\
\text { adenovirus }\end{array}$ & HER2 & I & NCT03740256 & $\begin{array}{l}\text { Bladder cancer, } \\
\text { HNSCC, salivary } \\
\text { gland cancer, lung } \\
\text { cancer, breast cancer, } \\
\text { gastric cancer, ESCA, } \\
\text { colorectal cancer, } \\
\text { pancreatic } \\
\text { adenocarcinoma }\end{array}$ & $\begin{array}{l}\text { Not yet } \\
\text { recruiting }\end{array}$ & $\begin{array}{l}\text { Baylor College } \\
\text { of Medicine }\end{array}$ \\
\hline
\end{tabular}




\section{Combination with chemotherapy}

In addition to reducing the tumor burden, chemotherapeutic agents perform considerable immunomodulatory functions. On the one hand, chemotherapeutic agents can stimulate tumor cells to release ATP or damage-associated molecular patterns, which increase the recruitment of DCs and $\mathrm{T}$ lymphocytes to infiltrate into tumor sites and promote the maturation and activation of DCs. On the other hand, chemotherapeutic agents may remodel the TME by selectively inhibiting the activity of immunosuppressive cells (such as Treg cells and MDSCs). Therefore, combining CAR T cells with chemotherapeutic agents may be a promising strategy to boost the anti-tumor efficacy of CAR T cell immunotherapy.

Numerous studies have confirmed this effect. For example, a preclinical study by Maher's group demonstrated that noncytotoxic doses of carboplatin sensitized tumor cells to ErbB-targeted CAR T cells and enhanced the efficacy of the anti-tumor response [190]. Pretreatment chemotherapy can counteract the potential immunogenicity of T cells and prolong the persistence of T cells [191]. In addition, chemotherapeutic agents, such as cyclophosphamide (CTX) and fludarabine, have been frequently utilized as a preconditioning regimen to deplete lymphocytes before infusion of CAR T cells in various clinical trials [192-197]. Brentjens' group revealed that the persistence of CAR19 T cells was significantly enhanced in patients with prior administration (2 days) of a relatively high dose of CTX [198]. Recent studies by Curran's group suggest that minimal pretreatment with CTX positively affects the CAR19 $\mathrm{T}$ cell response without negatively affecting the toxicity [192].

In conclusion, chemotherapeutic agents may be a feasible adjuvant for use with CAR T cell immunotherapy in the treatment of solid tumors. Further research on this combination strategy may provide an opportunity to harness the full potential of CAR T cells in the treatment of solid tumors.

\section{Combination with radiotherapy}

Recently, radiotherapy has been proposed as a popular adjunct therapy to improve the efficacy of tumor immunotherapy [199]. Radiotherapy not only can kill tumor cells directly but can also partially induce tumorspecific immune responses by heightening CTL recognition mediated through increased cell surface expression of MHC class I molecules and improved presentation of new peptides. In addition, radiotherapy leads to the release of proinflammatory cytokines and chemokines to moderate the TME. Thus, combining CAR T cell therapy with radiotherapy could lead to further improvements in CAR T cell therapy [200].
Preclinical studies by Weiss and colleagues [201] showed that radiotherapy resulted in synergistic activity in an orthotopic mouse model of glioblastoma by promoting the migration of $\mathrm{NK}$ group 2 member D (NKG2D)-targeted CAR T cells to the tumor site and increasing the effector functions. They also observed that radiation significantly induced the expression of NKG2D ligands on malignant cells, possibly explaining the synergy between the two methods described above. DeSelm and colleagues [202] further confirmed that low-dose radiation conditioning sensitizes tumor cells (not only $\mathrm{sLeA}^{+}$but also sLeA $^{-}$) to CARsLeA $\mathrm{T}$ cells in a model of heterogeneous pancreatic adenocarcinoma.

This finding suggests that the combination of radiotherapy and CAR T cell therapy can overcome antigennegative tumor escape and effectively eliminate heterogeneous tumors. The above studies provide a rationale for translating this combined immunotherapeutic strategy into clinical trials. Qu and colleagues [203] pretreated patients with radiotherapy or chemotherapy before infusion of CAR T cells for relapsed or refractory diffuse large B cell lymphoma and noted that radiotherapy is a safe and promising approach to enhance the efficacy of CAR T cell therapy. In conclusion, radiotherapy is an effective agent in combination with CAR T cells in solid tumors.

\section{Combination with biomaterials}

Given the success of immunotherapy, increasing research has focused on combining biomaterials with immunotherapy to enhance the efficacy against solid malignancies. Biomaterials have previously been designed as carriers to deliver patient-specific irradiated tumor cells, tumor lysates, or other stimulating signals to the local regions [204-206]. Currently, biomaterials are used to address the shortcomings of CAR T cells in cancer immunotherapy. Biomaterials not only improve the expansion of $\mathrm{T}$ cells in vitro but also enhance their in vivo efficacy. One of the important methods is the delivery of immunomodulating agents to recruit and facilitate the immune response against tumors. Nanoparticles are attractive biomaterials used by researchers to help in CAR T cell immunotherapy.

Nanoparticles were used to transport immunoagonists to the tumor site and stimulate anti-tumor effector cells prior to CAR T cell therapy in a breast cancer model $[207,208]$. Stephan et al. used lipid nanoparticles containing a potent drug cocktail to create a therapeutic window, and infusing CAR $T$ cells during this time frame enhanced the infiltration and robust expansion of CAR $\mathrm{T}$ cells and ultimately augmented the anti-tumor effect [209]. These findings were further confirmed in an immunotherapyresistant mouse model, in which nanoparticle preconditioning was conducive to CAR T cell therapy [209-212]. Smith's group further demonstrated that codelivery of 
STING agonists with CAR T cells in an alginate-based scaffold approach rendered CAR T cells with the ability to eradicate tumors effectively and simultaneously stimulated the endogenous immune response to eliminate tumor cells not recognized by CAR T cells [204].

\section{Outlook}

Utilizing CAR T cells to fight against malignancies marks the beginning of a new era of cancer treatment, and the remarkable success against hematologic malignancies is encouraging, supporting a proof-of-principle system to extend this treatment paradigm to other cancers. However, given the complexity of solid tumorigenesis, optimized CAR T cells are insufficient to overcome all the obstacles presented by solid tumors. Therefore, the combination of a variety of modifications to compensate for the shortcomings of CAR T cells and resolution of the challenges posed by solid tumors are necessary. In addition, mobilizing endogenous immune cells is necessary for CAR T cells to achieve the best therapeutic effect in solid tumors.

In this regard, the combinatorial approaches of CAR T cells have demonstrated tremendous potential in various preclinical solid models, several of which are already being transformed into clinical therapies. This promising combinatorial method shows the potential to stimulate immune cell activation and proliferation while counteracting immunosuppressive signals. However, the vigorous CAR $\mathrm{T}$ cells might seriously damage normal host tissues and lead to severe toxicities. Recently, different strategies have been developed to improve the safety of CAR T cells, including the identification of predictive biomarkers, design of safety switches, and exploration of novel ways to mitigate toxic drugs.

CAR T cells have matured from experimental studies to effective treatment options for patients with poor prognosis. However, this field is still in its infancy, and further research is needed to fully launch the potential of CAR T cells as a successful cancer treatment.

\section{Acknowledgements}

This work was supported by the National Natural Science Foundation of China (Nos. 31991171, 81830002, and 31540016) and National Key R\&D Program of China (No. 2018YFC1313400).

\section{Compliance with ethics guidelines}

Xiaohui Wang, Zhiqiang Wu, Wei Qiu, Ping Chen, Xiang Xu, and Weidong Han declare that they have no conflict of interest. This manuscript is a review article and does not involve a research protocol requiring approval by the relevant institutional review board or ethics committee.
Open Access This article is licensed under a Creative Commons Attribution 4.0 International License, which permits use, sharing, adaptation, distribution and reproduction in any medium or format, as long as you give appropriate credit to the original author(s) and the source, provide a link to the Creative Commons licence, and indicate if changes were made.

The images or other third party material in this article are included in the article's Creative Commons licence, unless indicated otherwise in a credit line to the material. If material is not included in the article's Creative Commons licence and your intended use is not permitted by statutory regulation or exceeds the permitted use, you will need to obtain permission directly from the copyright holder.

To view a copy of this licence, visit https://creativecommons.org/ licenses/by/4.0/.

\section{References}

1. Zhang C, Liu J, Zhong JF, Zhang X. Engineering CAR-T cells. Biomark Res 2017; 5(1): 22

2. Brudno JN, Kochenderfer JN. Chimeric antigen receptor T-cell therapies for lymphoma. Nat Rev Clin Oncol 2018; 15(1): 31-46

3. Ding G, Chen H. Adoptive transfer of $T$ cells transduced with a chimeric antigen receptor to treat relapsed or refractory acute leukemia: efficacy and feasibility of immunotherapy approaches. Sci China Life Sci 2016; 59(7): 673-677

4. Mikkilineni L, Kochenderfer JN. Chimeric antigen receptor T-cell therapies for multiple myeloma. Blood 2017; 130(24): 2594-2602

5. Wei G, Ding L, Wang J, Hu Y, Huang H. Advances of CD19directed chimeric antigen receptor-modified $\mathrm{T}$ cells in refractory/ relapsed acute lymphoblastic leukemia. Exp Hematol Oncol 2017; 6(1): 10

6. Yu S, Li A, Liu Q, Li T, Yuan X, Han X, Wu K. Chimeric antigen receptor T cells: a novel therapy for solid tumors. J Hematol Oncol 2017; 10(1): 78

7. Maude SL, Laetsch TW, Buechner J, Rives S, Boyer M, Bittencourt H, Bader P, Verneris MR, Stefanski HE, Myers GD, Qayed M, De Moerloose B, Hiramatsu H, Schlis K, Davis KL, Martin PL, Nemecek ER, Yanik GA, Peters C, Baruchel A, Boissel $\mathrm{N}$, Mechinaud F, Balduzzi A, Krueger J, June CH, Levine BL, Wood P, Taran T, Leung M, Mueller KT, Zhang Y, Sen K, Lebwohl D, Pulsipher MA, Grupp SA. Tisagenlecleucel in children and young adults with B-cell lymphoblastic leukemia. N Engl J Med 2018; 378(5): 439-448

8. Schuster SJ, Bishop MR, Tam CS, Waller EK, Borchmann P, McGuirk JP, Jäger U, Jaglowski S, Andreadis C, Westin JR, Fleury I, Bachanova V, Foley SR, Ho PJ, Mielke S, Magenau JM, Holte H, Pantano S, Pacaud LB, Awasthi R, Chu J, Anak Ö, Salles G, Maziarz RT; JULIET Investigators. Tisagenlecleucel in adult relapsed or refractory diffuse large B-cell lymphoma. N Engl J Med 2019; 380(1): 45-56

9. Neelapu SS, Locke FL, Bartlett NL, Lekakis LJ, Miklos DB, Jacobson CA, Braunschweig I, Oluwole OO, Siddiqi T, Lin Y, Timmerman JM, Stiff PJ, Friedberg JW, Flinn IW, Goy A, Hill BT, Smith MR, Deol A, Farooq U, McSweeney P, Munoz J, Avivi I, Castro JE, Westin JR, Chavez JC, Ghobadi A, Komanduri KV, 
Levy R, Jacobsen ED, Witzig TE, Reagan P, Bot A, Rossi J, Navale L, Jiang Y, Aycock J, Elias M, Chang D, Wiezorek J, Go WY. Axicabtagene ciloleucel CAR T-cell therapy in refractory large B-cell lymphoma. N Engl J Med 2017; 377(26): 2531-2544

10. Zah E, Lin MY, Silva-Benedict A, Jensen MC, Chen YY. T cells expressing CD19/CD20 bispecific chimeric antigen receptors prevent antigen escape by malignant B cells. Cancer Immunol Res 2016; 4(6): 498-508

11. Grada Z, Hegde M, Byrd T, Shaffer DR, Ghazi A, Brawley VS, Corder A, Schönfeld K, Koch J, Dotti G, Heslop HE, Gottschalk S, Wels WS, Baker ML, Ahmed N. TanCAR: a novel bispecific chimeric antigen receptor for cancer immunotherapy. Mol Ther Nucleic Acids 2013; 2: e105

12. Ruella M, Barrett DM, Kenderian SS, Shestova O, Hofmann TJ, Perazzelli J, Klichinsky M, Aikawa V, Nazimuddin F, Kozlowski M, Scholler J, Lacey SF, Melenhorst JJ, Morrissette JJ, Christian DA, Hunter CA, Kalos M, Porter DL, June CH, Grupp SA, Gill S. Dual CD19 and CD123 targeting prevents antigen-loss relapses after CD19-directed immunotherapies. J Clin Invest 2016; 126 (10): 3814-3826

13. Bielamowicz K, Fousek K, Byrd TT, Samaha H, Mukherjee M, Aware N, Wu MF, Orange JS, Sumazin P, Man TK, Joseph SK, Hegde M, Ahmed N. Trivalent CAR T cells overcome interpatient antigenic variability in glioblastoma. Neuro-oncol 2018; 20(4): 506-518

14. Straathof KC, Pulè MA, Yotnda P, Dotti G, Vanin EF, Brenner MK, Heslop HE, Spencer DM, Rooney CM. An inducible caspase 9 safety switch for T-cell therapy. Blood 2005; 105(11): 42474254

15. Di Stasi A, Tey SK, Dotti G, Fujita Y, Kennedy-Nasser A, Martinez C, Straathof K, Liu E, Durett AG, Grilley B, Liu H, Cruz CR, Savoldo B, Gee AP, Schindler J, Krance RA, Heslop HE, Spencer DM, Rooney CM, Brenner MK. Inducible apoptosis as a safety switch for adoptive cell therapy. N Engl J Med 2011; 365 (18): 1673-1683

16. Zhou X, Brenner MK. Improving the safety of T-cell therapies using an inducible caspase-9 gene. Exp Hematol 2016; 44(11): 1013-1019

17. Diaconu I, Ballard B, Zhang M, Chen Y, West J, Dotti G, Savoldo B. Inducible caspase-9 selectively modulates the toxicities of CD19-specific chimeric antigen receptor-modified T cells. Mol Ther 2017; 25(3): 580-592

18. Kenderian SS, Ruella M, Shestova O, Klichinsky M, Aikawa V, Morrissette JJ, Scholler J, Song D, Porter DL, Carroll M, June CH, Gill S. CD33-specific chimeric antigen receptor $\mathrm{T}$ cells exhibit potent preclinical activity against human acute myeloid leukemia. Leukemia 2015; 29(8): 1637-1647

19. Beatty GL, Haas AR, Maus MV, Torigian DA, Soulen MC, Plesa G, Chew A, Zhao Y, Levine BL, Albelda SM, Kalos M, June CH. Mesothelin-specific chimeric antigen receptor mRNA-engineered $\mathrm{T}$ cells induce anti-tumor activity in solid malignancies. Cancer Immunol Res 2014; 2(2): 112-120

20. Katz SC, Burga RA, McCormack E, Wang LJ, Mooring W, Point GR, Khare PD, Thorn M, Ma Q, Stainken BF, Assanah EO, Davies R, Espat NJ, Junghans RP. Phase I hepatic immunotherapy for metastases study of intra-arterial chimeric antigen receptormodified T-cell therapy for $\mathrm{CEA}^{+}$liver metastases. Clin Cancer
Res 2015; 21(14): 3149-3159

21. Tchou J, Zhao Y, Levine BL, Zhang PJ, Davis MM, Melenhorst JJ, Kulikovskaya I, Brennan AL, Liu X, Lacey SF, Posey AD Jr, Williams AD, So A, Conejo-Garcia JR, Plesa G, Young RM, McGettigan S, Campbell J, Pierce RH, Matro JM, DeMichele AM, Clark AS, Cooper LJ, Schuchter LM, Vonderheide RH, June CH. Safety and efficacy of intratumoral injections of chimeric antigen receptor (CAR) $\mathrm{T}$ cells in metastatic breast cancer. Cancer Immunol Res 2017; 5(12): 1152-1161

22. van Schalkwyk MC, Papa SE, Jeannon JP, Guerrero Urbano T, Spicer JF, Maher J. Design of a phase I clinical trial to evaluate intratumoral delivery of ErbB-targeted chimeric antigen receptor Tcells in locally advanced or recurrent head and neck cancer. Hum Gene Ther Clin Dev 2013; 24(3): 134-142

23. Harlin H, Meng Y, Peterson AC, Zha Y, Tretiakova M, Slingluff C, McKee M, Gajewski TF. Chemokine expression in melanoma metastases associated with $\mathrm{CD} 8^{+} \mathrm{T}$-cell recruitment. Cancer Res 2009; 69(7): 3077-3085

24. Cherkassky L, Morello A, Villena-Vargas J, Feng Y, Dimitrov DS, Jones DR, Sadelain M, Adusumilli PS. Human CAR T cells with cell-intrinsic PD-1 checkpoint blockade resist tumor-mediated inhibition. J Clin Invest 2016; 126(8): 3130-3144

25. Gajewski TF, Meng Y, Blank C, Brown I, Kacha A, Kline J, Harlin H. Immune resistance orchestrated by the tumor microenvironment. Immunol Rev 2006; 213(1): 131-145

26. Kershaw MH, Devaud C, John LB, Westwood JA, Darcy PK. Enhancing immunotherapy using chemotherapy and radiation to modify the tumor microenvironment. OncoImmunology 2013; 2 (9): e25962

27. Turley SJ, Cremasco V, Astarita JL. Immunological hallmarks of stromal cells in the tumour microenvironment. Nat Rev Immunol 2015; 15(11): 669-682

28. Motz GT, Santoro SP, Wang LP, Garrabrant T, Lastra RR, Hagemann IS, Lal P, Feldman MD, Benencia F, Coukos G. Tumor endothelium FasL establishes a selective immune barrier promoting tolerance in tumors. Nat Med 2014; 20(6): 607-615

29. Labanieh L, Majzner RG, Mackall CL. Programming CAR-T cells to kill cancer. Nat Biomed Eng 2018; 2(6): 377-391

30. Leonard JP, Sherman ML, Fisher GL, Buchanan LJ, Larsen G, Atkins MB, Sosman JA, Dutcher JP, Vogelzang NJ, Ryan JL. Effects of single-dose interleukin-12 exposure on interleukin-12associated toxicity and interferon- $\gamma$ production. Blood 1997; 90(7): 2541-2548

31. Chinnasamy D, Yu Z, Kerkar SP, Zhang L, Morgan RA, Restifo $\mathrm{NP}$, Rosenberg SA. Local delivery of interleukin-12 using T cells targeting VEGF receptor-2 eradicates multiple vascularized tumors in mice. Clin Cancer Res 2012; 18(6): 1672-1683

32. Pegram HJ, Purdon TJ, van Leeuwen DG, Curran KJ, Giralt SA, Barker JN, Brentjens RJ. IL-12-secreting CD19-targeted cord blood-derived $\mathrm{T}$ cells for the immunotherapy of B-cell acute lymphoblastic leukemia. Leukemia 2015; 29(2): 415-422

33. Hoyos V, Savoldo B, Quintarelli C, Mahendravada A, Zhang M, Vera J, Heslop HE, Rooney CM, Brenner MK, Dotti G. Engineering CD19-specific T lymphocytes with interleukin-15 and a suicide gene to enhance their anti-lymphoma/leukemia effects and safety. Leukemia 2010; 24(6): 1160-1170

34. Chmielewski M, Abken H. CAR T cells releasing IL-18 convert to 
T-Bet ${ }^{\text {high }}$ FoxO1 ${ }^{\text {low }}$ effectors that exhibit augmented activity against advanced solid tumors. Cell Reports 2017; 21(11): 32053219

35. Tang H, Wang Y, Chlewicki LK, Zhang Y, Guo J, Liang W, Wang $\mathrm{J}$, Wang $\mathrm{X}, \mathrm{Fu} \mathrm{YX}$. Facilitating $\mathrm{T}$ cell infiltration in tumor microenvironment overcomes resistance to PD-L1 blockade. Cancer Cell 2016; 29(3): 285-296

36. Zhang L, Kerkar SP, Yu Z, Zheng Z, Yang S, Restifo NP, Rosenberg SA, Morgan RA. Improving adoptive T cell therapy by targeting and controlling IL-12 expression to the tumor environment. Mol Ther 2011; 19(4): 751-759

37. Colombo MP, Trinchieri G. Interleukin-12 in anti-tumor immunity and immunotherapy. Cytokine Growth Factor Rev 2002; 13(2): 155-168

38. Wagner HJ, Bollard CM, Vigouroux S, Huls MH, Anderson R, Prentice HG, Brenner MK, Heslop HE, Rooney CM. A strategy for treatment of Epstein-Barr virus-positive Hodgkin's disease by targeting interleukin 12 to the tumor environment using tumor antigen-specific T cells. Cancer Gene Ther 2004; 11(2): 81-91

39. Pegram HJ, Lee JC, Hayman EG, Imperato GH, Tedder TF, Sadelain M, Brentjens RJ. Tumor-targeted $\mathrm{T}$ cells modified to secrete IL-12 eradicate systemic tumors without need for prior conditioning. Blood 2012; 119(18): 4133-4141

40. Chmielewski M, Hombach AA, Abken H. Of CARs and TRUCKs: chimeric antigen receptor (CAR) $\mathrm{T}$ cells engineered with an inducible cytokine to modulate the tumor stroma. Immunol Rev 2014; 257(1): 83-90

41. Chmielewski M, Kopecky C, Hombach AA, Abken H. IL-12 release by engineered $\mathrm{T}$ cells expressing chimeric antigen receptors can effectively muster an antigen-independent macrophage response on tumor cells that have shut down tumor antigen expression. Cancer Res 2011; 71(17): 5697-5706

42. Koneru M, Purdon TJ, Spriggs D, Koneru S, Brentjens RJ. IL-12 secreting tumor-targeted chimeric antigen receptor T cells eradicate ovarian tumors in vivo. OncoImmunology 2015; 4(3): e994446

43. Koneru M, O'Cearbhaill R, Pendharkar S, Spriggs DR, Brentjens RJ. A phase I clinical trial of adoptive T cell therapy using IL-12 secreting MUC-16(ecto) directed chimeric antigen receptors for recurrent ovarian cancer. J Transl Med 2015; 13(1): 102

44. Liu Y, Di S, Shi B, Zhang H, Wang Y, Wu X, Luo H, Wang H, Li $Z$, Jiang H. Armored inducible expression of IL-12 enhances antitumor activity of glypican-3-targeted chimeric antigen receptor-engineered $\mathrm{T}$ cells in hepatocellular carcinoma. J Immunol 2019; 203(1): 198-207

45. Hurton LV, Singh H, Najjar AM, Switzer KC, Mi T, Maiti S, Olivares S, Rabinovich B, Huls H, Forget MA, Datar V, Kebriaei P, Lee DA, Champlin RE, Cooper LJ. Tethered IL-15 augments antitumor activity and promotes a stem-cell memory subset in tumor-specific T cells. Proc Natl Acad Sci USA 2016; 113(48): E7788-E7797

46. Teague RM, Sather BD, Sacks JA, Huang MZ, Dossett ML, Morimoto J, Tan X, Sutton SE, Cooke MP, Ohlén C, Greenberg PD. Interleukin-15 rescues tolerant $\mathrm{CD}^{+} \mathrm{T}$ cells for use in adoptive immunotherapy of established tumors. Nat Med 2006; 12 (3): 335-341

47. Marks-Konczalik J, Dubois S, Losi JM, Sabzevari H, Yamada N, Feigenbaum L, Waldmann TA, Tagaya Y. IL-2-induced activation- induced cell death is inhibited in IL-15 transgenic mice. Proc Natl Acad Sci USA 2000; 97(21): 11445-11450

48. Klebanoff CA, Finkelstein SE, Surman DR, Lichtman MK, Gattinoni L, Theoret MR, Grewal N, Spiess PJ, Antony PA, Palmer DC, Tagaya Y, Rosenberg SA, Waldmann TA, Restifo NP. IL-15 enhances the in vivo antitumor activity of tumor-reactive $\mathrm{CD}^{+}$T cells. Proc Natl Acad Sci USA 2004; 101(7): 1969-1974

49. Mlecnik B, Bindea G, Angell HK, Sasso MS, Obenauf AC, Fredriksen T, Lafontaine L, Bilocq AM, Kirilovsky A, Tosolini M, Waldner M, Berger A, Fridman WH, Rafii A, Valge-Archer V, Pagès F, Speicher MR, Galon J. Functional network pipeline reveals genetic determinants associated with in situ lymphocyte proliferation and survival of cancer patients. Sci Transl Med 2014; 6(228): $228 \mathrm{ra3} 7$

50. Dadi S, Chhangawala S, Whitlock BM, Franklin RA, Luo CT, Oh SA, Toure A, Pritykin Y, Huse M, Leslie CS, Li MO. Cancer immunosurveillance by tissue-resident innate lymphoid cells and innate-like T cells. Cell 2016; 164(3): 365-377

51. Cheever MA. Twelve immunotherapy drugs that could cure cancers. Immunol Rev 2008; 222(1): 357-368

52. Hsu C, Hughes MS, Zheng Z, Bray RB, Rosenberg SA, Morgan RA. Primary human T lymphocytes engineered with a codonoptimized IL-15 gene resist cytokine withdrawal-induced apoptosis and persist long-term in the absence of exogenous cytokine. $\mathrm{J}$ Immunol 2005; 175(11): 7226-7234

53. Krenciute G, Prinzing BL, Yi Z, Wu MF, Liu H, Dotti G, Balyasnikova IV, Gottschalk S. Transgenic expression of IL15 improves antiglioma activity of IL13R $\alpha 2$-CAR T cells but results in antigen loss variants. Cancer Immunol Res 2017; 5(7): 571-581

54. Baldassarre G, Fedele M, Battista S, Vecchione A, Klein-Szanto AJ, Santoro M, Waldmann TA, Azimi N, Croce CM, Fusco A. Onset of natural killer cell lymphomas in transgenic mice carrying a truncated HMGI-C gene by the chronic stimulation of the IL-2 and IL-15 pathway. Proc Natl Acad Sci USA 2001; 98(14): 79707975

55. Badoual C, Bouchaud G, Agueznay NH, Mortier E, Hans S, Gey A, Fernani F, Peyrard S, -Puig PL, Bruneval P, Sastre X, Plet A, Garrigue-Antar L, Quintin-Colonna F, Fridman WH, Brasnu D, Jacques Y, Tartour E. The soluble $\alpha$ chain of interleukin-15 receptor: a proinflammatory molecule associated with tumor progression in head and neck cancer. Cancer Res 2008; 68(10): 3907-3914

56. Fabbi M, Ferrini S. Dual roles of IL-15 in cancer biology. J Cytokine Biol 2016; 1(2): 1000103

57. Robertson MJ, Kirkwood JM, Logan TF, Koch KM, Kathman S, Kirby LC, Bell WN, Thurmond LM, Weisenbach J, Dar MM. A dose-escalation study of recombinant human interleukin-18 using two different schedules of administration in patients with cancer. Clin Cancer Res 2008; 14(11): 3462-3469

58. Schwartzberg LS, Petak I, Stewart C, Turner PK, Ashley J, Tillman DM, Douglas L, Tan M, Billups C, Mihalik R, Weir A, Tauer K, Shope S, Houghton JA. Modulation of the Fas signaling pathway by IFN- $\gamma$ in therapy of colon cancer: phase I trial and correlative studies of IFN- $\gamma$, 5-fluorouracil, and leucovorin. Clin Cancer Res 2002; 8(8): 2488-2498

59. Hu B, Ren J, Luo Y, Keith B, Young RM, Scholler J, Zhao Y, June $\mathrm{CH}$. Augmentation of antitumor immunity by human and mouse 
CAR T cells secreting IL-18. Cell Rep 2017; 20(13): 3025-3033

60. Avanzi MP, Yeku O, Li X, Wijewarnasuriya DP, van Leeuwen DG, Cheung K, Park H, Purdon TJ, Daniyan AF, Spitzer MH, Brentjens RJ. Engineered tumor-targeted $\mathrm{T}$ cells mediate enhanced antitumor efficacy both directly and through activation of the endogenous immune system. Cell Rep 2018; 23(7): 2130-2141

61. Kwoczek J, Riese SB, Tischer S, Bak S, Lahrberg J, Oelke M, Maul H, Blasczyk R, Sauer M, Eiz-Vesper B. Cord blood-derived $\mathrm{T}$ cells allow the generation of a more naïve tumor-reactive cytotoxic T-cell phenotype. Transfusion 2018; 58(1): 88-99

62. Shum T, Omer B, Tashiro H, Kruse RL, Wagner DL, Parikh K, Yi Z, Sauer T, Liu D, Parihar R, Castillo P, Liu H, Brenner MK, Metelitsa LS, Gottschalk S, Rooney CM. Constitutive signaling from an engineered IL7 receptor promotes durable tumor elimination by tumor-redirected T cells. Cancer Discov 2017; 7 (11): 1238-1247

63. Markley JC, Sadelain M. IL-7 and IL-21 are superior to IL-2 and IL-15 in promoting human T cell-mediated rejection of systemic lymphoma in immunodeficient mice. Blood 2010; 115(17): 3508 3519

64. Stoiber S, Cadilha BL, Benmebarek MR, Lesch S, Endres S, Kobold S. Limitations in the design of chimeric antigen receptors for cancer therapy. Cells 2019; 8(5): E472

65. Yeku OO, Purdon TJ, Koneru M, Spriggs D, Brentjens RJ. Armored CAR T cells enhance antitumor efficacy and overcome the tumor microenvironment. Sci Rep 2017; 7(1): 10541

66. Martinez M, Moon EK. CAR T cells for solid tumors: new strategies for finding, infiltrating, and surviving in the tumor microenvironment. Front Immunol 2019; 10: 128

67. Mardiana S, Solomon BJ, Darcy PK, Beavis PA. Supercharging adoptive $\mathrm{T}$ cell therapy to overcome solid tumor-induced immunosuppression. Sci Transl Med 2019; 11(495): eaaw2293

68. Siddiqui I, Erreni M, van Brakel M, Debets R, Allavena P. Enhanced recruitment of genetically modified CX3CR1-positive human $\mathrm{T}$ cells into fractalkine/CX3CL1 expressing tumors: importance of the chemokine gradient. $\mathrm{J}$ Immunother Cancer 2016; 4(1): 21

69. Kershaw MH, Wang G, Westwood JA, Pachynski RK, Tiffany HL, Marincola FM, Wang E, Young HA, Murphy PM, Hwu P. Redirecting migration of $\mathrm{T}$ cells to chemokine secreted from tumors by genetic modification with CXCR2. Hum Gene Ther 2002; 13(16): 1971-1980

70. Slaney CY, Kershaw MH, Darcy PK. Trafficking of T cells into tumors. Cancer Res 2014; 74(24): 7168-7174

71. Craddock JA, Lu A, Bear A, Pule M, Brenner MK, Rooney CM, Foster AE. Enhanced tumor trafficking of GD2 chimeric antigen receptor $\mathrm{T}$ cells by expression of the chemokine receptor CCR2b. J Immunother 2010; 33(8): 780-788

72. Moon EK, Carpenito C, Sun J, Wang LC, Kapoor V, Predina J, Powell DJ Jr, Riley JL, June CH, Albelda SM. Expression of a functional CCR2 receptor enhances tumor localization and tumor eradication by retargeted human $\mathrm{T}$ cells expressing a mesothelinspecific chimeric antibody receptor. Clin Cancer Res 2011; 17(14): 4719-4730

73. Xu Y, Hyun YM, Lim K, Lee H, Cummings RJ, Gerber SA, Bae S, Cho TY, Lord EM, Kim M. Optogenetic control of chemokine receptor signal and T-cell migration. Proc Natl Acad Sci USA
2014; 111(17): 6371-6376

74. Peng W, Ye Y, Rabinovich BA, Liu C, Lou Y, Zhang M, Whittington M, Yang Y, Overwijk WW, Lizée G, Hwu P. Transduction of tumor-specific T cells with CXCR2 chemokine receptor improves migration to tumor and antitumor immune responses. Clin Cancer Res 2010; 16(22): 5458-5468

75. Hickman HD, Reynoso GV, Ngudiankama BF, Cush SS, Gibbs J, Bennink JR, Yewdell JW. CXCR3 chemokine receptor enables local $\mathrm{CD} 8^{+} \mathrm{T}$ cell migration for the destruction of virus-infected cells. Immunity 2015; 42(3): 524-537

76. Asai H, Fujiwara H, An J, Ochi T, Miyazaki Y, Nagai K, Okamoto S, Mineno J, Kuzushima K, Shiku H, Inoue H, Yasukawa M. Cointroduced functional CCR2 potentiates in vivo anti-lung cancer functionality mediated by $\mathrm{T}$ cells double gene-modified to express WT1-specific T-cell receptor. PLoS One 2013; 8(2): e56820

77. Müller N, Michen S, Tietze S, Töpfer K, Schulte A, Lamszus K, Schmitz M, Schackert G, Pastan I, Temme A. Engineering NK cells modified with an EGFRvIII-specific chimeric antigen receptor to overexpress CXCR4 improves immunotherapy of CXCL12/SDF-1 $\alpha$-secreting glioblastoma. J Immunother 2015; 38 (5): $197-210$

78. Di Stasi A, De Angelis B, Rooney CM, Zhang L, Mahendravada A, Foster AE, Heslop HE, Brenner MK, Dotti G, Savoldo B. T lymphocytes coexpressing CCR4 and a chimeric antigen receptor targeting CD30 have improved homing and antitumor activity in a Hodgkin tumor model. Blood 2009; 113(25): 6392-6402

79. Whilding LM, Halim L, Draper B, Parente-Pereira AC, Zabinski T, Davies DM, Maher J. CAR T-cells targeting the integrin $\alpha v \beta 6$ and co-expressing the chemokine receptor CXCR2 demonstrate enhanced homing and efficacy against several solid malignancies. Cancers (Basel) 2019; 11(5): E674

80. Duong CP, Yong CS, Kershaw MH, Slaney CY, Darcy PK. Cancer immunotherapy utilizing gene-modified T cells: from the bench to the clinic. Mol Immunol 2015; 67(2 Pt A): 46-57

81. Kunert A, Straetemans T, Govers C, Lamers C, Mathijssen R, Sleijfer S, Debets R. TCR-engineered T cells meet new challenges to treat solid tumors: choice of antigen, $\mathrm{T}$ cell fitness, and sensitization of tumor milieu. Front Immunol 2013; 4: 363

82. Melero I, Rouzaut A, Motz GT, Coukos G. T-cell and NK-cell infiltration into solid tumors: a key limiting factor for efficacious cancer immunotherapy. Cancer Discov 2014; 4(5): 522-526

83. Kim ST, Jeong H, Woo OH, Seo JH, Kim A, Lee ES, Shin SW, Kim YH, Kim JS, Park KH. Tumor-infiltrating lymphocytes, tumor characteristics, and recurrence in patients with early breast cancer. Am J Clin Oncol 2013; 36(3): 224-231

84. Galon J, Costes A, Sanchez-Cabo F, Kirilovsky A, Mlecnik B, Lagorce-Pagès $\mathrm{C}$, Tosolini $\mathrm{M}$, Camus $\mathrm{M}$, Berger $\mathrm{A}$, Wind $\mathrm{P}$, Zinzindohoué F, Bruneval P, Cugnenc PH, Trajanoski Z, Fridman WH, Pagès F. Type, density, and location of immune cells within human colorectal tumors predict clinical outcome. Science 2006; 313(5795): 1960-1964

85. Adachi K, Kano Y, Nagai T, Okuyama N, Sakoda Y, Tamada K. IL-7 and CCL19 expression in CAR-T cells improves immune cell infiltration and CAR-T cell survival in the tumor. Nat Biotechnol 2018; 36(4): 346-351

86. Mauri DN, Ebner R, Montgomery RI, Kochel KD, Cheung TC, Yu GL, Ruben S, Murphy M, Eisenberg RJ, Cohen GH, Spear PG, 
Ware CF. LIGHT, a new member of the TNF superfamily, and lymphotoxin $\alpha$ are ligands for herpesvirus entry mediator. Immunity 1998; 8(1): 21-30

87. Tamada K, Shimozaki K, Chapoval AI, Zhai Y, Su J, Chen SF, Hsieh SL, Nagata S, Ni J, Chen L. LIGHT, a TNF-like molecule, costimulates $\mathrm{T}$ cell proliferation and is required for dendritic cellmediated allogeneic $\mathrm{T}$ cell response. J Immunol 2000; 164(8): 4105-4110

88. Morel Y, Schiano de Colella JM, Harrop J, Deen KC, Holmes SD, Wattam TA, Khandekar SS, Truneh A, Sweet RW, Gastaut JA, Olive D, Costello RT. Reciprocal expression of the TNF family receptor herpes virus entry mediator and its ligand LIGHT on activated T cells: LIGHT down-regulates its own receptor. J Immunol 2000; 165(8): 4397-4404

89. Ware CF. Network communications: lymphotoxins, LIGHT, and TNF. Annu Rev Immunol 2005; 23(1): 787-819

90. Wang Y, Zhu M, Miller M, Fu YX. Immunoregulation by tumor necrosis factor superfamily member LIGHT. Immunol Rev 2009; 229(1): 232-243

91. Fu YX, Chaplin DD. Development and maturation of secondary lymphoid tissues. Annu Rev Immunol 1999; 17(1): 399-433

92. Yu P, Fu YX. Targeting tumors with LIGHT to generate metastasis-clearing immunity. Cytokine Growth Factor Rev 2008; 19(3-4): 285-294

93. Yu P, Lee Y, Liu W, Chin RK, Wang J, Wang Y, Schietinger A, Philip M, Schreiber H, Fu YX. Priming of naive T cells inside tumors leads to eradication of established tumors. Nat Immunol 2004; 5(2): 141-149

94. Yu P, Lee Y, Wang Y, Liu X, Auh S, Gajewski TF, Schreiber H, You Z, Kaynor C, Wang X, Fu YX. Targeting the primary tumor to generate CTL for the effective eradication of spontaneous metastases. J Immunol 2007; 179(3): 1960-1968

95. Tang H, Wang Y, Chlewicki LK, Zhang Y, Guo J, Liang W, Wang $\mathrm{J}$, Wang $\mathrm{X}, \mathrm{Fu} \mathrm{YX}$. Facilitating $\mathrm{T}$ cell infiltration in tumor microenvironment overcomes resistance to PD-L1 blockade. Cancer Cell 2016; 30(3): 500

96. Armitage RJ, Fanslow WC, Strockbine L, Sato TA, Clifford KN, Macduff BM, Anderson DM, Gimpel SD, Davis-Smith T, Maliszewski CR, Clark EA, Smith CA, Grabstein KH, Cosman D, Spriggs MK. Molecular and biological characterization of a murine ligand for CD40. Nature 1992; 357(6373): 80-82

97. Armant M, Armitage R, Boiani N, Delespesse G, Sarfati M. Functional CD40 ligand expression on $\mathrm{T}$ lymphocytes in the absence of $\mathrm{T}$ cell receptor engagement: involvement in interleukin2-induced interleukin-12 and interferon-gamma production. Eur J Immunol 1996; 26(7): 1430-1434

98. Bhadra R, Gigley JP, Khan IA. Cutting edge: CD40-CD40 ligand pathway plays a critical CD8-intrinsic and-extrinsic role during rescue of exhausted CD8 T cells. J Immunol 2011; 187(9): 44214425

99. Bourgeois C, Rocha B, Tanchot C. A role for CD40 expression on $\mathrm{CD} 8{ }^{+} \mathrm{T}$ cells in the generation of $\mathrm{CD} 8^{+} \mathrm{T}$ cell memory. Science 2002; 297(5589): 2060-2063

100. Frentsch M, Stark R, Matzmohr N, Meier S, Durlanik S, Schulz AR, Stervbo U, Jürchott K, Gebhardt F, Heine G, Reuter MA, Betts MR, Busch D, Thiel A. CD40L expression permits CD8 ${ }^{+} \mathrm{T}$ cells to execute immunologic helper functions. Blood 2013; 122
(3): 405-412

101. Liu Y, Qureshi M, Xiang J. Antitumor immune responses derived from transgenic expression of CD40 ligand in myeloma cells. Cancer Biother Radiopharm 2002; 17(1): 11-18

102. Liu Y, Xia D, Li F, Zheng C, Xiang J. Intratumoral administration of immature dendritic cells following the adenovirus vector encoding CD40 ligand elicits significant regression of established myeloma. Cancer Gene Ther 2005; 12(2): 122-132

103. Schönbeck U, Libby P. The CD40/CD154 receptor/ligand dyad. Cell Mol Life Sci 2001; 58(1): 4-43

104. Elmetwali T, Young LS, Palmer DH. CD40 ligand-induced carcinoma cell death: a balance between activation of TNFRassociated factor (TRAF) 3-dependent death signals and suppression of TRAF6-dependent survival signals. J Immunol 2010; 184 (2): 1111-1120

105. Angelou A, Antoniou E, Garmpis N, Damaskos C, Theocharis S, Margonis GA. The role of soluble CD40L ligand in human carcinogenesis. Anticancer Res 2018; 38(5): 3199-3201

106. Kato K, Cantwell MJ, Sharma S, Kipps TJ. Gene transfer of CD40ligand induces autologous immune recognition of chronic lymphocytic leukemia B cells. J Clin Invest 1998; 101(5): 11331141

107. Vonderheide RH, Glennie MJ. Agonistic CD40 antibodies and cancer therapy. Clin Cancer Res 2013; 19(5): 1035-1043

108. Vonderheide RH, Burg JM, Mick R, Trosko JA, Li D, Shaik MN, Tolcher AW, Hamid O. Phase I study of the CD40 agonist antibody CP-870,893 combined with carboplatin and paclitaxel in patients with advanced solid tumors. OncoImmunology 2013; 2(1): e23033

109. Beatty GL, Chiorean EG, Fishman MP, Saboury B, Teitelbaum UR, Sun W, Huhn RD, Song W, Li D, Sharp LL, Torigian DA, O'Dwyer PJ, Vonderheide RH. CD40 agonists alter tumor stroma and show efficacy against pancreatic carcinoma in mice and humans. Science 2011; 331(6024): 1612-1616

110. Wierda WG, Cantwell MJ, Woods SJ, Rassenti LZ, Prussak CE, Kipps TJ. CD40-ligand (CD154) gene therapy for chronic lymphocytic leukemia. Blood 2000; 96(9): 2917-2924

111. Wierda WG, Castro JE, Aguillon R, Sampath D, Jalayer A, McMannis J, Prussak CE, Keating M, Kipps TJ. A phase I study of immune gene therapy for patients with CLL using a membranestable, humanized CD154. Leukemia 2010; 24(11): 1893-1900

112. Castro JE, Melo-Cardenas J, Urquiza M, Barajas-Gamboa JS, Pakbaz RS, Kipps TJ. Gene immunotherapy of chronic lymphocytic leukemia: a phase I study of intranodally injected adenovirus expressing a chimeric CD154 molecule. Cancer Res 2012; 72(12): 2937-2948

113. Curran KJ, Seinstra BA, Nikhamin Y, Yeh R, Usachenko Y, van Leeuwen DG, Purdon T, Pegram HJ, Brentjens RJ. Enhancing antitumor efficacy of chimeric antigen receptor $\mathrm{T}$ cells through constitutive CD40L expression. Mol Ther 2015; 23(4): 769-778

114. Kuhn NF, Purdon TJ, van Leeuwen DG, Lopez AV, Curran KJ, Daniyan AF, Brentjens RJ. CD40 ligand-modified chimeric antigen receptor $\mathrm{T}$ cells enhance antitumor function by eliciting an endogenous antitumor response. Cancer Cell 2019; 35(3): 473488.e6

115. Heyman B, Yang Y. Chimeric antigen receptor T cell therapy for solid tumors: current status, obstacles and future strategies. Cancers (Basel) 2019; 11(2): E191 
116. Yoon DH, Osborn MJ, Tolar J, Kim CJ. Incorporation of immune checkpoint blockade into chimeric antigen receptor T cells (CARTs): combination or built-in CAR-T. Int J Mol Sci 2018; 19(2): E340

117. Brahmer J, Reckamp KL, Baas P, Crinò L, Eberhardt WE, Poddubskaya E, Antonia S, Pluzanski A, Vokes EE, Holgado E, Waterhouse D, Ready N, Gainor J, Arén Frontera O, Havel L, Steins M, Garassino MC, Aerts JG, Domine M, Paz-Ares L, Reck M, Baudelet C, Harbison CT, Lestini B, Spigel DR. Nivolumab versus docetaxel in advanced squamous-cell non-small-cell lung cancer. N Engl J Med 2015; 373(2): 123-135

118. Larkin J, Chiarion-Sileni V, Gonzalez R, Grob JJ, Cowey CL, Lao CD, Schadendorf D, Dummer R, Smylie M, Rutkowski P, Ferrucci PF, Hill A, Wagstaff J, Carlino MS, Haanen JB, Maio M, MarquezRodas I, McArthur GA, Ascierto PA, Long GV, Callahan MK, Postow MA, Grossmann K, Sznol M, Dreno B, Bastholt L, Yang A, Rollin LM, Horak C, Hodi FS, Wolchok JD. Combined nivolumab and ipilimumab or monotherapy in untreated melanoma. N Engl J Med 2015; 373(1): 23-34

119. Motzer RJ, Escudier B, McDermott DF, George S, Hammers HJ, Srinivas S, Tykodi SS, Sosman JA, Procopio G, Plimack ER, Castellano D, Choueiri TK, Gurney H, Donskov F, Bono P, Wagstaff J, Gauler TC, Ueda T, Tomita Y, Schutz FA, Kollmannsberger C, Larkin J, Ravaud A, Simon JS, Xu LA, Waxman IM, Sharma P; CheckMate 025 Investigators. Nivolumab versus everolimus in advanced renal-cell carcinoma. N Engl J Med 2015; 373(19): 1803-1813

120. Kochenderfer JN, Dudley ME, Kassim SH, Somerville RP, Carpenter RO, Stetler-Stevenson M, Yang JC, Phan GQ, Hughes MS, Sherry RM, Raffeld M, Feldman S, Lu L, Li YF, Ngo LT, Goy A, Feldman T, Spaner DE, Wang ML, Chen CC, Kranick SM, Nath A, Nathan DA, Morton KE, Toomey MA, Rosenberg SA. Chemotherapy-refractory diffuse large B-cell lymphoma and indolent B-cell malignancies can be effectively treated with autologous $\mathrm{T}$ cells expressing an anti-CD19 chimeric antigen receptor. J Clin Oncol 2015; 33(6): 540-549

121. Brudno JN, Somerville RP, Shi V, Rose JJ, Halverson DC, Fowler DH, Gea-Banacloche JC, Pavletic SZ, Hickstein DD, Lu TL, Feldman SA, Iwamoto AT, Kurlander R, Maric I, Goy A, Hansen BG, Wilder JS, Blacklock-Schuver B, Hakim FT, Rosenberg SA, Gress RE, Kochenderfer JN. Allogeneic T cells that express an anti-CD19 chimeric antigen receptor induce remissions of B-cell malignancies that progress after allogeneic hematopoietic stem-cell transplantation without causing graft-versus-host disease. J Clin Oncol 2016; 34(10): 1112-1121

122. Eyquem J, Mansilla-Soto J, Giavridis T, van der Stegen SJ, Hamieh M, Cunanan KM, Odak A, Gönen M, Sadelain M. Targeting a CAR to the TRAC locus with CRISPR/Cas9 enhances tumour rejection. Nature 2017; 543(7643): 113-117

123. Keir ME, Butte MJ, Freeman GJ, Sharpe AH. PD-1 and its ligands in tolerance and immunity. Annu Rev Immunol 2008; 26(1): 677704

124. Li S, Siriwon N, Zhang X, Yang S, Jin T, He F, Kim YJ, Mac J, Lu Z, Wang S, Han X, Wang P. Enhanced cancer immunotherapy by chimeric antigen receptor-modified $\mathrm{T}$ cells engineered to secrete checkpoint inhibitors. Clin Cancer Res 2017; 23(22): 6982-6992

125. Kuryk L, Møller AW, Jaderberg M. Combination of immunogenic oncolytic adenovirus ONCOS-102 with anti-PD-1 pembrolizumab exhibits synergistic antitumor effect in humanized A2058 melanoma huNOG mouse model. OncoImmunology 2019; 8(2): e1532763

126. Wang H, Kaur G, Sankin AI, Chen F, Guan F, Zang X. Immune checkpoint blockade and CAR-T cell therapy in hematologic malignancies. J Hematol Oncol 2019; 12(1): 59

127. Li AM, Hucks GE, Dinofia AM, Seif AE, Teachey DT, Baniewicz D, Callahan C, Fasano C, McBride B, Gonzalez V, Nazimuddin F, Porter DL, Lacey SF, June CH, Grupp SA, Maude SL. Checkpoint inhibitors augment CD19-directed chimeric antigen receptor (CAR) $\mathrm{T}$ cell therapy in relapsed B-cell acute lymphoblastic leukemia. American Society of Hematology Annual Meeting. 2018. San Diego, California. Blood 2018; 132 (Supplement 1): 556

128. John LB, Devaud C, Duong CP, Yong CS, Beavis PA, Haynes NM, Chow MT, Smyth MJ, Kershaw MH, Darcy PK. Anti-PD-1 antibody therapy potently enhances the eradication of established tumors by gene-modified T cells. Clin Cancer Res 2013; 19(20): 5636-5646

129. Heczey A, Louis CU, Savoldo B, Dakhova O, Durett A, Grilley B, Liu H, Wu MF, Mei Z, Gee A, Mehta B, Zhang H, Mahmood N, Tashiro H, Heslop HE, Dotti G, Rooney CM, Brenner MK. CAR T cells administered in combination with lymphodepletion and PD-1 inhibition to patients with neuroblastoma. Mol Ther 2017; 25(9): 2214-2224

130. Suarez ER, Chang K, Sun J, Sui J, Freeman GJ, Signoretti S, Zhu Q, Marasco WA. Chimeric antigen receptor T cells secreting antiPD-L1 antibodies more effectively regress renal cell carcinoma in a humanized mouse model. Oncotarget 2016; 7(23): 34341-34355

131. Prosser ME, Brown CE, Shami AF, Forman SJ, Jensen MC. Tumor PD-L1 co-stimulates primary human $\mathrm{CD}^{+}$cytotoxic $\mathrm{T}$ cells modified to express a PD1:CD28 chimeric receptor. Mol Immunol 2012; 51(3-4): 263-272

132. Ren J, Liu X, Fang C, Jiang S, June CH, Zhao Y. Multiplex genome editing to generate universal CAR T Cells resistant to PD1 inhibition. Clin Cancer Res 2017; 23(9): 2255-2266

133. Rupp LJ, Schumann K, Roybal KT, Gate RE, Ye CJ, Lim WA, Marson A. CRISPR/Cas9-mediated PD-1 disruption enhances anti-tumor efficacy of human chimeric antigen receptor T cells. Sci Rep 2017; 7(1): 737

134. Hu W, Zi Z, Jin Y, Li G, Shao K, Cai Q, Ma X, Wei F. CRISPR/ Cas9-mediated PD-1 disruption enhances human mesothelintargeted CAR T cell effector functions. Cancer Immunol Immunother 2019; 68(3): 365-377

135. Vicente D, Lee AJ, Hall CS, Lucci A, Lee JE, Kim MP, Katz MHG, Hurd MW, Maitra A, Rhim Md AD, Tzeng CD. Circulating tumor cells and transforming growth factor $\beta$ in resected pancreatic adenocarcinoma. J Surg Res 2019; 243: 90-99

136. Roca H, Craig MJ, Ying C, Varsos ZS, Czarnieski P, Alva AS, Hernandez J, Fuller D, Daignault S, Healy PN, Pienta KJ. IL-4 induces proliferation in prostate cancer PC3 cells under nutrientdepletion stress through the activation of the JNK-pathway and survivin up-regulation. J Cell Biochem 2012; 113(5): 1569-1580

137. Achkova D, Maher J. Role of the colony-stimulating factor (CSF)/ CSF-1 receptor axis in cancer. Biochem Soc Trans 2016; 44(2): 333-341

138. Siegel PM, Massagué J. Cytostatic and apoptotic actions of TGF- $\beta$ 
in homeostasis and cancer. Nat Rev Cancer 2003; 3(11): 807-821

139. Hanahan D, Weinberg RA. Hallmarks of cancer: the next generation. Cell 2011; 144(5): 646-674

140. Travis MA, Sheppard D. TGF- $\beta$ activation and function in immunity. Annu Rev Immunol 2014; 32(1): 51-82

141. Gupta A, Budhu S, Merghoub T. One checkpoint may hide another: inhibiting the TGF $\beta$ signaling pathway enhances immune checkpoint blockade. Hepatobiliary Surg Nutr 2019; 8(3): 289294

142. Dahmani A, Delisle JS. TGF- $\beta$ in T cell biology: implications for cancer immunotherapy. Cancers (Basel) 2018; 10(6): E194

143. Wrzesinski SH, Wan YY, Flavell RA. Transforming growth factor$\beta$ and the immune response: implications for anticancer therapy. Clin Cancer Res 2007; 13(18 Pt 1): 5262-5270

144. Zhang L, Yu Z, Muranski P, Palmer DC, Restifo NP, Rosenberg SA, Morgan RA. Inhibition of TGF- $\beta$ signaling in genetically engineered tumor antigen-reactive $\mathrm{T}$ cells significantly enhances tumor treatment efficacy. Gene Ther 2013; 20(5): 575-580

145. Ostroukhova M, Seguin-Devaux C, Oriss TB, Dixon-McCarthy B, Yang L, Ameredes BT, Corcoran TE, Ray A. Tolerance induced by inhaled antigen involves $\mathrm{CD}^{+} \mathrm{T}$ cells expressing membranebound TGF- $\beta$ and FOXP3. J Clin Invest 2004; 114(1): 28-38

146. Kloss CC, Lee J, Zhang A, Chen F, Melenhorst JJ, Lacey SF, Maus MV, Fraietta JA, Zhao Y, June CH. Dominant-negative TGF- $\beta$ receptor enhances PSMA-targeted human CAR T cell proliferation and augments prostate cancer eradication. Mol Ther 2018; 26(7): 1855-1866

147. Chang ZL, Lorenzini MH, Chen X, Tran U, Bangayan NJ, Chen YY. Rewiring T-cell responses to soluble factors with chimeric antigen receptors. Nat Chem Biol 2018; 14(3): 317-324

148. Sukumaran S, Watanabe N, Bajgain P, Raja K, Mohammed S, Fisher WE, Brenner MK, Leen AM, Vera JF. Enhancing the potency and specificity of engineered T cells for cancer treatment. Cancer Discov 2018; 8(8): 972-987

149. Pangault C, Amé-Thomas P, Ruminy P, Rossille D, Caron G, Baia M, De Vos J, Roussel M, Monvoisin C, Lamy T, Tilly H, Gaulard $\mathrm{P}$, Tarte K, Fest T. Follicular lymphoma cell niche: identification of a preeminent IL-4-dependent T(FH)-B cell axis. Leukemia 2010; 24(12): 2080-2089

150. Todaro M, Lombardo Y, Francipane MG, Alea MP, Cammareri P, Iovino F, Di Stefano AB, Di Bernardo C, Agrusa A, Condorelli G, Walczak H, Stassi G. Apoptosis resistance in epithelial tumors is mediated by tumor-cell-derived interleukin-4. Cell Death Differ 2008; 15(4): 762-772

151. Parronchi P, De Carli M, Manetti R, Simonelli C, Sampognaro S, Piccinni MP, Macchia D, Maggi E, Del Prete G, Romagnani S. IL4 and IFN ( $\alpha$ and $\gamma$ ) exert opposite regulatory effects on the development of cytolytic potential by Th1 or Th2 human T cell clones. J Immunol 1992; 149(9): 2977-2983

152. Schoenborn JR, Wilson CB. Regulation of interferon- $\gamma$ during innate and adaptive immune responses. Adv Immunol 2007; 96: 41-101

153. Jackson RJ, Ramsay AJ, Christensen CD, Beaton S, Hall DF, Ramshaw IA. Expression of mouse interleukin- 4 by a recombinant ectromelia virus suppresses cytolytic lymphocyte responses and overcomes genetic resistance to mousepox. J Virol 2001; 75(3): $1205-1210$
154. Brady J, Carotta S, Thong RP, Chan CJ, Hayakawa Y, Smyth MJ, Nutt SL. The interactions of multiple cytokines control NK cell maturation. J Immunol 2010; 185(11): 6679-6688

155. Wilkie S, Burbridge SE, Chiapero-Stanke L, Pereira AC, Cleary S, van der Stegen SJ, Spicer JF, Davies DM, Maher J. Selective expansion of chimeric antigen receptor-targeted T-cells with potent effector function using interleukin-4. J Biol Chem 2010; 285(33): 25538-25544

156. Mohammed S, Sukumaran S, Bajgain P, Watanabe N, Heslop HE, Rooney CM, Brenner MK, Fisher WE, Leen AM, Vera JF. Improving chimeric antigen receptor-modified $\mathrm{T}$ cell function by reversing the immunosuppressive tumor microenvironment of pancreatic cancer. Mol Ther 2017; 25(1): 249-258

157. Abate-Daga D, Lagisetty KH, Tran E, Zheng Z, Gattinoni L, Yu Z, Burns WR, Miermont AM, Teper Y, Rudloff U, Restifo NP, Feldman SA, Rosenberg SA, Morgan RA. A novel chimeric antigen receptor against prostate stem cell antigen mediates tumor destruction in a humanized mouse model of pancreatic cancer. Hum Gene Ther 2014; 25(12): 1003-1012

158. Wolpin BM, O’Reilly EM, Ko YJ, Blaszkowsky LS, Rarick M, Rocha-Lima CM, Ritch P, Chan E, Spratlin J, Macarulla T, McWhirter E, Pezet D, Lichinitser M, Roman L, Hartford A, Morrison K, Jackson L, Vincent M, Reyno L, Hidalgo M. Global, multicenter, randomized, phase II trial of gemcitabine and gemcitabine plus AGS-1C4D4 in patients with previously untreated, metastatic pancreatic cancer. Ann Oncol 2013; 24(7): 1792-1801

159. Kacinski BM. CSF-1 and its receptor in ovarian, endometrial and breast cancer. Ann Med 1995; 27(1): 79-85

160. Smith HO, Anderson PS, Kuo DY, Goldberg GL, DeVictoria CL, Boocock CA, Jones JG, Runowicz CD, Stanley ER, Pollard JW. The role of colony-stimulating factor 1 and its receptor in the etiopathogenesis of endometrial adenocarcinoma. Clin Cancer Res 1995; 1(3): 313-325

161. Stanley ER, Berg KL, Einstein DB, Lee PS, Pixley FJ, Wang Y, Yeung YG. Biology and action of colony-stimulating factor-1. Mol Reprod Dev 1997; 46(1): 4-10

162. Lo AS, Taylor JR, Farzaneh F, Kemeny DM, Dibb NJ, Maher J. Harnessing the tumour-derived cytokine, CSF-1, to co-stimulate Tcell growth and activation. Mol Immunol 2008; 45(5): 1276-1287

163. Russell SJ, Barber GN. Oncolytic viruses as antigen-agnostic cancer vaccines. Cancer Cell 2018; 33(4): 599-605

164. Russell SJ, Peng KW, Bell JC. Oncolytic virotherapy. Nat Biotechnol 2012; 30(7): 658-670

165. Keller BA, Bell JC. Oncolytic viruses-immunotherapeutics on the rise. J Mol Med (Berl) 2016; 94(9): 979-991

166. Russell L, Peng KW. The emerging role of oncolytic virus therapy against cancer. Chin Clin Oncol 2018; 7(2): 16

167. Bauzon M, Hermiston T. Armed therapeutic viruses - a disruptive therapy on the horizon of cancer immunotherapy. Front Immunol 2014; 5 : 74

168. Guedan S, Rojas JJ, Gros A, Mercade E, Cascallo M, Alemany R. Hyaluronidase expression by an oncolytic adenovirus enhances its intratumoral spread and suppresses tumor growth. Mol Ther 2010; 18(7): 1275-1283

169. Guedan S, Grases D, Rojas JJ, Gros A, Vilardell F, Vile R, Mercade E, Cascallo M, Alemany R. GALV expression enhances 
the therapeutic efficacy of an oncolytic adenovirus by inducing cell fusion and enhancing virus distribution. Gene Ther 2012; 19(11): 1048-1057

170. Fajardo CA, Guedan S, Rojas LA, Moreno R, Arias-Badia M, de Sostoa J, June CH, Alemany R. Oncolytic adenoviral delivery of an EGFR-targeting T-cell engager improves antitumor efficacy. Cancer Res 2017; 77(8): 2052-2063

171. Cody JJ, Douglas JT. Armed replicating adenoviruses for cancer virotherapy. Cancer Gene Ther 2009; 16(6): 473-488

172. Bommareddy PK, Shettigar M, Kaufman HL. Integrating oncolytic viruses in combination cancer immunotherapy. Nat Rev Immunol 2018; 18(8): 498-513

173. Twumasi-Boateng K, Pettigrew JL, Kwok YYE, Bell JC, Nelson $\mathrm{BH}$. Oncolytic viruses as engineering platforms for combination immunotherapy. Nat Rev Cancer 2018; 18(7): 419-432

174. Ribas A, Dummer R, Puzanov I, VanderWalde A, Andtbacka RHI, Michielin O, Olszanski AJ, Malvehy J, Cebon J, Fernandez E, Kirkwood JM, Gajewski TF, Chen L, Gorski KS, Anderson AA, Diede SJ, Lassman ME, Gansert J, Hodi FS, Long GV. Oncolytic virotherapy promotes intratumoral $\mathrm{T}$ cell infiltration and improves anti-PD-1 immunotherapy. Cell 2017; 170(6): 1109-1119.e10

175. Chesney J, Puzanov I, Collichio F, Singh P, Milhem MM, Glaspy J, Hamid O, Ross M, Friedlander P, Garbe C, Logan TF, Hauschild A, Lebbé C, Chen L, Kim JJ, Gansert J, Andtbacka RHI, Kaufman HL. Randomized, open-label phase II study evaluating the efficacy and safety of talimogene laherparepvec in combination with ipilimumab versus ipilimumab alone in patients with advanced, unresectable melanoma. J Clin Oncol 2018; 36(17): 1658-1667

176. Carew JF, Kooby DA, Halterman MW, Kim SH, Federoff HJ, Fong Y. A novel approach to cancer therapy using an oncolytic herpes virus to package amplicons containing cytokine genes. Mol Ther 2001; 4(3): 250-256

177. Stephenson KB, Barra NG, Davies E, Ashkar AA, Lichty BD. Expressing human interleukin-15 from oncolytic vesicular stomatitis virus improves survival in a murine metastatic colon adenocarcinoma model through the enhancement of anti-tumor immunity. Cancer Gene Ther 2012; 19(4): 238-246

178. Li J, O’Malley M, Urban J, Sampath P, Guo ZS, Kalinski P, Thorne SH, Bartlett DL. Chemokine expression from oncolytic vaccinia virus enhances vaccine therapies of cancer. Mol Ther 2011; 19(4): 650-657

179. Dias JD, Hemminki O, Diaconu I, Hirvinen M, Bonetti A, Guse K, Escutenaire S, Kanerva A, Pesonen S, Löskog A, Cerullo V, Hemminki A. Targeted cancer immunotherapy with oncolytic adenovirus coding for a fully human monoclonal antibody specific for CTLA-4. Gene Ther 2012; 19(10): 988-998

180. Engeland CE, Grossardt C, Veinalde R, Bossow S, Lutz D, Kaufmann JK, Shevchenko I, Umansky V, Nettelbeck DM, Weichert W, Jäger D, von Kalle C, Ungerechts G. CTLA-4 and PD-L1 checkpoint blockade enhances oncolytic measles virus therapy. Mol Ther 2014; 22(11): 1949-1959

181. Kleinpeter P, Fend L, Thioudellet C, Geist M, Sfrontato N, Koerper V, Fahrner C, Schmitt D, Gantzer M, Remy-Ziller C, Brandely R, Villeval D, Rittner K, Silvestre N, Erbs P, Zitvogel L, Quéméneur E, Préville X, Marchand JB. Vectorization in an oncolytic vaccinia virus of an antibody, a Fab and a scFv against programmed cell death-1 (PD-1) allows their intratumoral delivery and an improved tumor-growth inhibition. OncoImmunology
2016; 5(10): e1220467

182. Watanabe K, Luo Y, Da T, Guedan S, Ruella M, Scholler J, Keith B, Young RM, Engels B, Sorsa S, Siurala M, Havunen R, Tähtinen $\mathrm{S}$, Hemminki A, June $\mathrm{CH}$. Pancreatic cancer therapy with combined mesothelin-redirected chimeric antigen receptor $\mathrm{T}$ cells and cytokine-armed oncolytic adenoviruses. JCI Insight 2018; 3 (7): 99573

183. Moon EK, Wang LS, Bekdache K, Lynn RC, Lo A, Thorne SH, Albelda SM. Intra-tumoral delivery of CXCL11 via a vaccinia virus, but not by modified $\mathrm{T}$ cells, enhances the efficacy of adoptive $\mathrm{T}$ cell therapy and vaccines. OncoImmunology 2018; 7(3): e1395997

184. Lichty BD, Breitbach CJ, Stojdl DF, Bell JC. Going viral with cancer immunotherapy. Nat Rev Cancer 2014; 14(8): 559-567

185. Tanoue K, Rosewell Shaw A, Watanabe N, Porter C, Rana B, Gottschalk S, Brenner M, Suzuki M. Armed oncolytic adenovirusexpressing PD-L1 mini-body enhances antitumor effects of chimeric antigen receptor $\mathrm{T}$ cells in solid tumors. Cancer Res 2017; 77(8): 2040-2051

186. Rosewell Shaw A, Porter CE, Watanabe N, Tanoue K, Sikora A, Gottschalk S, Brenner MK, Suzuki M. Adenovirotherapy delivering cytokine and checkpoint inhibitor augments CAR T cells against metastatic head and neck cancer. Mol Ther 2017; 25(11): 2440-2451

187. Qiao J, Wang H, Kottke T, Diaz RM, Willmon C, Hudacek A, Thompson J, Parato K, Bell J, Naik J, Chester J, Selby P, Harrington K, Melcher A, Vile RG. Loading of oncolytic vesicular stomatitis virus onto antigen-specific $\mathrm{T}$ cells enhances the efficacy of adoptive T-cell therapy of tumors. Gene Ther 2008; 15(8): 604616

188. Cole C, Qiao J, Kottke T, Diaz RM, Ahmed A, Sanchez-Perez L, Brunn G, Thompson J, Chester J, Vile RG. Tumor-targeted, systemic delivery of therapeutic viral vectors using hitchhiking on antigen-specific T cells. Nat Med 2005; 11(10): 1073-1081

189. VanSeggelen H, Tantalo DG, Afsahi A, Hammill JA, Bramson JL. Chimeric antigen receptor-engineered $\mathrm{T}$ cells as oncolytic virus carriers. Mol Ther Oncolytics 2015; 2: 15014

190. Parente-Pereira AC, Whilding LM, Brewig N, van der Stegen SJ, Davies DM, Wilkie S, van Schalkwyk MC, Ghaem-Maghami S, Maher J. Synergistic chemoimmunotherapy of epithelial ovarian cancer using ErbB-retargeted T cells combined with carboplatin. J Immunol 2013; 191(5): 2437-2445

191. Muranski P, Boni A, Wrzesinski C, Citrin DE, Rosenberg SA, Childs R, Restifo NP. Increased intensity lymphodepletion and adoptive immunotherapy - how far can we go? Nat Clin Pract Oncol 2006; 3(12): 668-681

192. Curran KJ, Margossian S, Kernan NA, Silverman LB, Williams DA, Shukla NN, Kobos R, Forlenza C, Steinherz P, Prockop S, Boulad F, Spitzer B, Cancio MI, Boelens JJ, Kung AL, Szenes VZ, Park J, Sauter CS, Heller G, Wang X, Senechal B, O'Reilly RJ, Riviere I, Sadelain M, Brentjens RJ. Toxicity and response following CD19-specific CAR T cells in pediatric/young adult relapsed/refractory B-ALL. Blood 2019; 134(26): 2361-2368

193. Hirayama AV, Gauthier J, Hay KA, Voutsinas JM, Wu Q, Pender BS, Hawkins RM, Vakil A, Steinmetz RN, Riddell SR, Maloney DG, Turtle CJ. High rate of durable complete remission in follicular lymphoma after CD19 CAR-T cell immunotherapy. Blood 2019; 134(7): 636-640 
194. Haas AR, Tanyi JL, O'Hara MH, Gladney WL, Lacey SF, Torigian DA, Soulen MC, Tian L, McGarvey M, Nelson AM, Farabaugh CS, Moon E, Levine BL, Melenhorst JJ, Plesa G, June CH, Albelda SM, Beatty GL. Phase I study of lentiviral-transduced chimeric antigen receptor-modified $\mathrm{T}$ cells recognizing mesothelin in advanced solid cancers. Mol Ther 2019; 27(11): 1919-1929

195. Brudno JN, Maric I, Hartman SD, Rose JJ, Wang M, Lam N, Stetler-Stevenson M, Salem D, Yuan C, Pavletic S, Kanakry JA, Ali SA, Mikkilineni L, Feldman SA, Stroncek DF, Hansen BG, Lawrence J, Patel R, Hakim F, Gress RE, Kochenderfer JN. T cells genetically modified to express an anti-B-cell maturation antigen chimeric antigen receptor cause remissions of poor-prognosis relapsed multiple myeloma. J Clin Oncol 2018; 36(22): 2267-2280

196. Zhang WY, Liu Y, Wang Y, Nie J, Guo YL, Wang CM, Dai HR, Yang QM, Wu ZQ, Han WD. Excessive activated T-cell proliferation after anti-CD19 CAR T-cell therapy. Gene Ther 2018; 25(3): 198-204

197. Feng K, Liu Y, Guo Y, Qiu J, Wu Z, Dai H, Yang Q, Wang Y, Han W. Phase I study of chimeric antigen receptor modified $T$ cells in treating HER2-positive advanced biliary tract cancers and pancreatic cancers. Protein Cell 2018; 9(10): 838-847

198. Brentjens RJ, Rivière I, Park JH, Davila ML, Wang X, Stefanski J, Taylor C, Yeh R, Bartido S, Borquez-Ojeda O, Olszewska M, Bernal Y, Pegram H, Przybylowski M, Hollyman D, Usachenko Y, Pirraglia D, Hosey J, Santos E, Halton E, Maslak P, Scheinberg D, Jurcic J, Heaney M, Heller G, Frattini M, Sadelain M. Safety and persistence of adoptively transferred autologous CD19-targeted T cells in patients with relapsed or chemotherapy refractory B-cell leukemias. Blood 2011; 118(18): 4817-4828

199. Shevtsov M, Sato H, Multhoff G, Shibata A. Novel approaches to improve the efficacy of immuno-radiotherapy. Front Oncol 2019; 9: 156

200. Minn I, Rowe SP, Pomper MG. Enhancing CAR T-cell therapy through cellular imaging and radiotherapy. Lancet Oncol 2019; 20 (8): e443-e451

201. Weiss T, Weller M, Guckenberger M, Sentman CL, Roth P. NKG2D-based CAR $\mathrm{T}$ cells and radiotherapy exert synergistic efficacy in glioblastoma. Cancer Res 2018; 78(4): 1031-1043

202. DeSelm C, Palomba ML, Yahalom J, Hamieh M, Eyquem J, Rajasekhar VK, Sadelain M. Low-dose radiation conditioning enables CAR T cells to mitigate antigen escape. Mol Ther 2018; 26 (11): 2542-2552

203. Qu C, Ping N, Wu Q, Kang L, Xia F, Yu L, Wu D, Jin Z. Radiotherapy priming chimeric antigen receptor $\mathrm{T}$ cell therapy is a safe and promising approach in relapsed/refractory diffuse large B cell lymphoma patients with high tumor burden. Blood 2018; 132 (Suppl 1): 2961

204. Smith TT, Moffett HF, Stephan SB, Opel CF, Dumigan AG, Jiang X, Pillarisetty VG, Pillai SPS, Wittrup KD, Stephan MT. Biopolymers codelivering engineered T cells and STING agonists can eliminate heterogeneous tumors. J Clin Invest 2017; 127(6): 2176-2191

205. Bencherif SA, Warren Sands R, Ali OA, Li WA, Lewin SA, Braschler TM, Shih TY, Verbeke CS, Bhatta D, Dranoff G, Mooney DJ. Injectable cryogel-based whole-cell cancer vaccines. Nat Commun 2015; 6(1): 7556

206. Kim J, Li WA, Choi Y, Lewin SA, Verbeke CS, Dranoff G, Mooney DJ. Injectable, spontaneously assembling, inorganic scaffolds modulate immune cells in vivo and increase vaccine efficacy. Nat Biotechnol 2015; 33(1): 64-72

207. Pulaski BA, Ostrand-Rosenberg S. Mouse $4 \mathrm{~T} 1$ breast tumor model. Curr Protoc Immunol, 2001. Chapter 20: Unit 20.2

208. Bailey-Downs LC, Thorpe JE, Disch BC, Bastian A, Hauser PJ, Farasyn T, Berry WL, Hurst RE, Ihnat MA. Development and characterization of a preclinical model of breast cancer lung micrometastatic to macrometastatic progression. PLoS One 2014; 9(5): e98624

209. Zhang F, Stephan SB, Ene CI, Smith TT, Holland EC, Stephan MT. Nanoparticles that reshape the tumor milieu create a therapeutic window for effective T-cell therapy in solid malignancies. Cancer Res 2018; 78(13): 3718-3730

210. Hambardzumyan D, Amankulor NM, Helmy KY, Becher OJ, Holland EC. Modeling adult gliomas using RCAS/t-va technology. Transl Oncol 2009; 2(2): 89-95

211. Weller M, Butowski N, Tran DD, Recht LD, Lim M, Hirte H, Ashby L, Mechtler L, Goldlust SA, Iwamoto F, Drappatz J, O'Rourke DM, Wong M, Hamilton MG, Finocchiaro G, Perry J, Wick W, Green J, He Y, Turner CD, Yellin MJ, Keler T, Davis TA, Stupp R, Sampson JH; ACT IV trial investigators. Rindopepimut with temozolomide for patients with newly diagnosed, EGFRvIIIexpressing glioblastoma (ACT IV): a randomised, double-blind, international phase 3 trial. Lancet Oncol 2017; 18(10): 1373-1385

212. Ahmed N, Brawley V, Hegde M, Bielamowicz K, Kalra M, Landi D, Robertson C, Gray TL, Diouf O, Wakefield A, Ghazi A, Gerken C, Yi Z, Ashoori A, Wu MF, Liu H, Rooney C, Dotti G, Gee A, Su J, Kew Y, Baskin D, Zhang YJ, New P, Grilley B, Stojakovic M, Hicks J, Powell SZ, Brenner MK, Heslop HE, Grossman R, Wels WS, Gottschalk S. HER2-specific chimeric antigen receptormodified virus-specific $\mathrm{T}$ cells for progressive glioblastoma: a phase 1 dose-escalation trial. JAMA Oncol 2017; 3(8): 1094-1101 